UNIVERSIDADE DE SÃO PAULO

DEPARTAMENTO DE CIÊNCIA POLÍTICA

Lincoln Narcelio Thomaz Noronha

\title{
PROCESSO LEGISLATIVO E EMENDAMENTO CONSTITUCIONAL NO BRASIL PÓS-1988
}

SÃO PAULO 
Lincoln Narcelio Thomaz Noronha

\section{PROCESSO LEGISLATIVO E EMENDAMENTO CONSTITUCIONAL NO BRASIL PÓS-1988}

Dissertação apresentada à Faculdade de Filosofia, Letras e Ciências Humanas da Universidade de São Paulo para obtenção do título de Mestre em Ciência Política.

Área de Concentração: Instituições Políticas.

Orientador: Prof. Rogério Bastos Arantes

\section{SÃO PAULO}


Folha de aprovação

Nome: Lincoln Narcelio Thomaz Noronha

Título: Processo Legislativo e Emendamento Constitucional no Brasil pós-1988

Dissertação apresentada à Faculdade de Filosofia, Letras e Ciências Humanas da Universidade de São Paulo para obtenção do título de Mestre em Ciência Política.

Área de Concentração: Instituições Políticas

Aprovado em:

\section{Banca Examinadora}

Prof. Dr. Rogério Bastos Arantes (Orientador) Instituição: DCP/USP

Assinatura:

Prof(a). Dr(a).:

Instituição: Assinatura:

$\operatorname{Prof(a).~Dr(a).:~}$

Instituição: Assinatura: 


\section{AGRADECIMENTOS}

Gostaria de agradecer,

Primeiramente aos professores Rogério e Cláudio, por terem trazido de volta à minha vida o prazer de estudar;

Ao pessoal de estudos legislativos do CEBRAP, por terem me recebido tão bem na USP, e por terem auxiliado ao longo desse trabalho com reflexões valiosas sobre processo legislativo. Em especial, gostaria de agradecer ao Danilo Medeiros, por ter disponibilizado seu próprio banco de PECs, o que me ajudou como um valioso mapa no início da minha pesquisa;

Aos professores Mathew Taylor e Fernando Limongi, pela paciência de ler esse trabalho quando ele ainda era uma mera tentativa de amarrar uma ideia, e pelos comentários que ajudaram na sua evolução;

Ao Sérgio Praça, à Simone Diniz e à Vanessa Elias, por terem me presenteado com novos quebra-cabeças;

Á minha família, por terem ao mesmo tempo a coragem de discordar e a força para apoiar. 


\section{RESUMO}

NORONHA, Lincoln N. T. Processo Legislativo e Emendamento Constitucional no Brasil pós-1988. 2011. (74)f. Dissertação (Mestrado) - Faculdade de Filosofia, Letras e Ciência Humanas, Universidade de São Paulo, 2011.

Este trabalho avalia o impacto do processo legislativo no emendamento da Constituição brasileira de 1988, até 2010. O objetivo é melhor explicar o contínuo crescimento e detalhamento da Constituição. Para tanto, foram elaboradas hipóteses a partir da literatura sobre a interação entre Executivo e Legislativo no sistema político brasileiro. As duas principais hipóteses testadas são 1) dominância do Executivo no emendamento constitucional, a partir do funcionamento do presidencialismo de coalizão; e 2) influência do poder legislativo no emendamento constitucional, ilustrando os custos do processo decisório e a relação entre a heterogeneidade de uma base política parlamentar e seu impacto na produção legislativa. Para a construção do banco de dados, foi utilizada a Metodologia de Análise Constitucional (MAC). Aplicou-se a metodologia às propostas de emenda constitucional (PECs) que se tornaram emendas à Constituição, assim como a todos os substitutivos aprovados nas fases deliberativas internas ao Congresso Nacional. Dessa maneira, foi possível avaliar cada mudança realizada em cada dispositivo das PECs oferecidas e aprovadas ao longo do processo legislativo, assim como o quanto cada fase contribuiu para a definição do texto final das emendas e para o detalhamento e crescimento do texto constitucional. Os resultados permitiram a comprovação da preponderância da hipótese 2 em detrimento da 1 , demonstrando a importância do Poder Legislativo na definição de matéria legislativa constitucional, em detrimento das propostas do Poder Executivo. Além disso, foi possível realizar uma crítica às teorias comparativas que relacionam o impacto da regra de emendamento nas taxas de emendamento das Constituições, demonstrando que, pelo menos no caso brasileiro, a combinação de maiorias qualificadas e heterogeneidade parlamentar levou a um aumento no emendamento da Constituição de 1988. 


\begin{abstract}
This work evaluates the impact of the legislative process on the brazilian constitution, from 1988 to 2010. It's objective is to better explain the continuous growth and growing specificity of the constitution. In order to do that, hypotheses were elaborated from the literature on the interaction between the Executive and Legislative branches of the brazilian political system. The two main hypotheses tested here are 1) Is the Executive dominant in the constitutional amendment process, through the mechanism of coalitional presidency; and 2) the influence of the Legislative on the constitutional amendment, illustrating the costs of the decision making process and the relation between an heterogeneous parliamentary base, and its impact on the legislation. To test these two hypotheses, a data set was gathered, using the Methodology of Constitutional Analysis (MCA). The MCA was applied to all the constitutional amendment proposals (CAPs) that eventually became constitutional amendments, as well as to all the substitute versions of the CAPs that were approved on the various deliberative forums inside the National Congress. By doing that, it was possible to evaluate each change made to the PECs that eventually became amendments to the constitution, as well as how each moment of the legislative process contributed to the growth of the constitutional text. The results proved the prevalence of the hypothesis 1 over the hypothesis 2 , thus demonstrating the importance of the Legislative branch in defining the contents of the constitution. Furthermore, it was possible develop a criticism on the current comparative theories on constitutional amendment that relates formal procedures of amendment and constitutional rigidity to rate of constitutional amendment. At least in the brazilian case, we observed that the combination of qualified majorities and parliamentary heterogeneity further spurred, and didn't restrict, constitutional amendment.
\end{abstract}


INTRODUÇÃO 08

1. PROCESSO LEGISLATIVO E EMENDAMENTO DA CONSTITUIÇÃO BRASILEIRA DE 1988

Perfil Constitucional, Governo de Coalizão e Explicações para o Contínuo

Emendamento 12

2. GOVERNANDO PARA ALÉM DO MANDATO OU NEGOCIANDO NO

LEGISLATIVO? 21

2.1. A unidade de análise: como medir textos e mudanças constitucionais ...... 21

2.2. Medindo Constituições 24

2.3. O impacto do processo legislativo na Constituição de 1988 29

2.4. O impacto do processo legislativo nas políticas públicas constitucionalizadas 44

2.5. Conclusões 52

3. RIGIDEZ CONSTITUCIONAL E EMENDAMENTO

CONSTITUCIONAL 56

3.1. Problemas Metodológicos 56

3.2. Rigidez Constitucional e Atores com Poderes de Veto 61

3.3. Regra de Emendamento e Impacto do Sistema Político Brasileiro no Emendamento da Constituição de 1988 66

3.4. Conclusões 68

4. BIBLIOGRAFIA 70 


\section{INTRODUÇÃOO}

O peculiar perfil constitucional brasileiro vem sendo fruto de crescente atenção tanto de autores e trabalhos brasileiros, quanto de pesquisadores estrangeiros que se assombram com diversas peculiaridades da Carta de 1988. Fruto de um processo constituinte altamente descentralizado, num contexto de transição democrática e reorganização das forças políticas pelo País afora, a Constituição que saiu do Congresso Nacional de 1988 espanta e maravilha estudiosos do tema pelo seu tamanho, abrangência de temas, detalhamento, quantidade de direitos e regulações sobre o funcionamento do Estado.

Esse perfil peculiar imediatamente trouxe sentimentos ambíguos em relação ao legado de 1988. De um lado muitos se regozijaram pelo que consideraram avanços em direção a um país mais igualitário e democrático, antevistos nas linhas do texto constitucional. Do outro, críticos se enfileiraram para reclamar do anacronismo de uma Constituição que continha em si uma série de disposições de políticas públicas específicas, reflexo ainda do apagar de luzes de uma realidade econômica que não mais era possível sustentar. As dificuldades para estruturar o jogo político democrático no final dos anos 80 e início dos anos 90, e para implementar as reformas econômicas e sociais que batiam violentamente à porta do país, apenas contribuíram para a visão negativa do texto de 1988 , que era visto como mais um empecilho à capacidade de qualquer um governar o país.

Não demorou para um estranho fenômeno constitucional capturar a atenção política do país, e em particular de analistas, juristas e cientistas humanos em geral. Apenas sete anos depois de sua promulgação, a Constituição de 1988 começou a ser mudada por emendas cada vez maiores e mais frequentes. Conforme o mito da ingovernabilidade do país se sublimava ante os olhos de todos, os clamores contra a destruição, o retalho constitucional e o fim dos direitos aumentaram, mas o texto seguiu sendo emendado duas, três, quatro, cinco e até mesmo seis vezes (em 1996) por ano, à despeito da grita. E não foram emendas pequenas, apesar de que, curiosamente, não se sentiram mudanças avassaladores na vida política do país, o que poderia se esperar de tamanha criatividade constitucional.

Apesar de diversos trabalhos analisando mudanças constitucionais e reformas econômicas e sociais específicas, somente no final da primeira metade dos anos 2000 é que a ciência política parece ter resolvido fazer um apanhado geral do fenômeno, tentar 
entender o que, afinal de contas, havia acontecido com o texto original de 1988, explicar o porquê de tanta mudança e, finalmente, se isso se tornaria algo constante da vida política do país, como parecia estar acontecendo.

Dos trabalhos que começaram a aparecer mais fortemente na segunda metade dos anos 2000, confirmou-se a impressão sobre o tamanho e detalhamento anormais do texto constitucional, que já estava presente lá durante os trabalhos constituintes entre 1987-1988, conforme pode ser exemplificado pela fala do relator geral da constituinte, Bernardo Cabral:

"Tem-se argumentado que a boa técnica de elaboração constitucional determina que a Constituição deva ser formalmente sintética. Todavia, é preciso que observemos a tendência das Constituições brasileiras no sentido de procurar regular, com bastante minúcia, aquilo que deseja implantar como norma de conduta dos negócios públicos e privados. Os constituintes têm desejado introduzir no texto constitucional regras que lhe fogem à natureza por versarem sobre matérias que melhor se enquadram em diplomas de legislação ordinária. "l

Mais ainda, confirmando-se as suspeitas, descobriu-se que esse detalhismo era pelo menos parcialmente responsável pelo revisionismo constitucional. Contudo, um fato novo foi descoberto, que vinha na esteira contrária do lugar comum que aparecia na mídia acerca do retalhamento e aleijamento da Constituição de 1988 via emendamento: o texto original na realidade não estava sendo reduzido, mas vinha crescendo consideravelmente como resultado das emendas constantemente feitas.

No âmbito internacional, ao mesmo tempo, muita atenção foi dada ao nascimento e evolução das novas Constituições que apareceram com as redemocratizações ocorridas na América Latina e na Europa. Um desenvolvimento recente desses estudos foi tentar compreender exatamente a relação entre regras de emendamento, as taxas de emendamento constitucional, e mesmo a morte de Constituições.

Esse trabalho vem no encontro dessas duas linhas de desenvolvimento recentes. A curiosidade sobre o contínuo crescimento e detalhamento no texto constitucional brasileiro, e uma insatisfação com as teorias e as metodologias que procuraram

\footnotetext{
${ }^{1}$ Bernardo Cabral em: Assembléia Nacional Constituinte. Comissão de Sistematização. Projeto de Constituição - Substitutivo do Relator. Brasília, Centro Gráfico do Senado Federal, agosto de 1987.
} 
relacionar regra de emendamento a mudança constitucional me levou a investigar mais detidamente o que aconteceu com as propostas de emendas constitucionais que foram aprovadas no Congresso Nacional de 1988 para cá. Minha insatisfação com as teorias que relacionam regras de emendamento ao emendamento constitucional vinha do fato desses trabalhos não levarem em conta a dimensão partidária para avaliar o quanto, de fato, determinada regra serve ou não como limitação ao emendamento de uma Constituição.

Para compreender o que ocorreu com as PECs aprovadas durante a sua tramitação no Congresso Nacional, e produzir hipóteses sobre o impacto do processo legislativo no emendamento da Constituição de 1988, tive de me voltar à rica literatura sobre processo legislativo brasileiro. Já para quantificar as mudanças ao longo da aprovação de uma PEC, recorri principalmente ao Método de Análise Constitucional, inicialmente desenvolvido por Arantes e Couto, que me permite quantificar textos legais em geral e suas mudanças ao longo do tempo, e no caso especificamente de textos constitucionais, permite também determinar e quantificar em quais pontos ocorre o detalhismo de uma Constituição.

A seguir, seguem meus achados sobre o tema. Esse trabalho está dividido em duas partes. Na primeira, recupero a literatura sobre processo legislativo e a interação entre Executivo e Legislativo para traçar hipóteses sobre qual é o mecanismo que explica o constante crescimento da Constituição. Nessa mesma parte, exponho meus resultados, com considerações adicionais sobre o impacto da interação entre Executivo e Legislativo no emendamento constitucional, e sobre o funcionamento do mecanismo do constante detalhamento constitucional no Brasil, à luz dos avanços e limites proporcionados pela teoria por trás da Metodologia de Análise Constitucional.

$\mathrm{Na}$ segunda parte, faço uma crítica às teorias que relacionam maior rigidez constitucional à diminuição no emendamento de Constituições, à luz da necessidade de incorporar sistemas políticos na análise. Essa crítica é feita a partir de três frentes. Primeiramente, levanto problemas metodológicos com os trabalhos recentes. Num segundo momento, recupero a teoria dos atores com poderes de veto para explicitar a necessidade de avaliar a dispersão espacial dos atores em relação às regras de emendamento. Por fim, recupero as conclusões da primeira parte, para demonstrar que é possível que o recurso a regras supermaiorias para reduzir a mudança de determinadas 
matérias legislativas que foram constitucionalizadas, pode na realidade levar a mais, e não a menos emendamento constitucional.

O trabalho também é acompanhado por um apêndice metodológico que trás diversas questões práticas sobre como medir Constituições. 


\section{PROCESSO LEgISLATIVO E EMENDAMENTO DA CONSTITUIÇÃo BRASILEIRA DE 1988}

Meu objetivo aqui é explorar a interação entre sistema político e emendamento constitucional, observando as alterações feitas às propostas de emenda constitucional (PECs) que foram aprovadas pelo Congresso Nacional brasileiro de 1988 até o final de 2010.

A compreensão do emendamento constitucional se torna importante por diferentes razões. Os custos políticos diferenciados exigidos pelos procedimentos que prevêem a alteração de uma carta podem implicar trade-offs entre a capacidade de um sistema político produzir decisões e a possibilidade da manutenção de decisões tomadas $^{2}$, e entender essa relação se torna tão mais importante quanto se tornar corriqueira a mudança constitucional. Do lado do texto, a constante alteração constitucional também pode trazer impacto à aplicabilidade das leis, e estabilidade institucional $^{3}$. Por fim, a própria noção de democracia pode ser questionada em países onde a expressão das maiorias produzidas pelas urnas necessita constantemente da anuência de minorias para ser posta em prática ${ }^{4}$.

\section{Perfil Constitucional, Governo de Coalizão e Hipóteses para o Contínuo Emendamento}

Um dos primeiros textos a abordar especificamente a relação entre o sistema político brasileiro e o texto da Constituição ainda o fez na chave da ingovernabilidade política do Brasil, ligando a dificuldade de o Brasil realizar as reformas econômicas contextuais da década de 90, ao fato de diversos temas pouco usuais e bastante específicos virem a serem tratados no marco constitucional (Couto 1997). Apesar do diagnóstico da ingovernabilidade ter caído por terra, em parte pelo sucesso de diferentes Presidentes de dois partidos políticos terem conseguido implementar agendas próprias de reformas no país, e em parte por análises como a de Figueiredo e Limongi (1999) que explicam como um sistema tão altamente fragmentado, dando espaço a uma

\footnotetext{
${ }^{2}$ Cox e McCubbins (1999) argumentam que o aumento de pontos de veto em um sistema político possui uma correlação inversa com a sua habilidade de produzir decisões e, ao mesmo tempo, uma correlação direta com a capacidade de se comprometer com decisões tomadas.

${ }^{3}$ Mesmo defendendo a necessidade de que Constituições sejam emendadas para se adequarem às mudanças no tempo, tanto Lutz (2006) quanto Elkins, Ginsburg e Melton (2009) argumentam que um número excessivo de emendas constitucionais pode ser prenuncio da morte de uma Constituição, além de produzirem problemas de enforcement.

${ }^{4}$ Para uma discussão teórica compreensiva sobre a tensão entre constitucionalismo e democracia, Elster, Jon e Slagstad, Rune (2001).
} 
heterogeneidade de preferências, consegue produzir decisões, ainda assim não se sabe muito bem qual o impacto dessas características sobre as agendas dos governos e nem, do outro lado, como isso afeta o emendamento da Constituição.

Por um lado existem os trabalhos produzidos a partir de Figueiredo e Limongi (1999), que salientam a importância dos incentivos criados na arena parlamentar para a ação partidária e coordenada dos congressistas, segundo o compasso dado pelo Executivo Federal ${ }^{5}$. Esses incentivos provêm tanto da capacidade do executivo interferir diretamente na arena legislativa (pedido de urgência, medida provisória, poderes de veto), quanto da própria organização dos trabalhos parlamentares ser feita em bases partidárias (mesa diretora e colégio de líderes) que por sua vez se conectam aos interesses do Executivo na distribuição do portfólio ministerial. O resultado seria a cartelização do processo legislativo ao estilo parlamentarista, tornando quase que irrelevante a distinção teórica entre parlamentarismo e presidencialismo (Amorim Neto, Cox e McCubbins 2003).

Do outro lado, existem os trabalhos que inicialmente apontavam para a paralisia decisória de um sistema político com múltiplos pontos de veto, no qual o Executivo é refém de um legislativo repleto de parlamentares que se comportam de maneira atomizada e sem nenhuma coerência ideológica, produzidos por uma arena eleitoral que desfavorece a formação de partidos, e favorece o comportamento clientelista e regionalista (Sartori 1994, Couto 1997, Abrúcio 1998, Mainwaring 1999, Ames 2003). Após os trabalhos de Figueiredo e Limongi, entre outros, essa perspectiva abandonou a teoria da paralisia decisória, porém ainda tematiza os custos do processo decisório, criados pelos múltiplos vetos do sistema político, e tende a qualificar o Executivo como refém do legislativo, independente de o sistema ser eficiente em produzir decisões ou não. O próprio trabalho de Arantes e Couto (2006, 2008 e 2009) - o qual é parte importante dessa pesquisa por tratar diretamente do problema do emendamento constitucional - se insere de maneira mais próxima dessa segunda perspectiva, ao salientar os custos do processo decisório embutidos na constitucionalização de políticas públicas, porém os autores não chegam a afirmar que isso gere problemas de governabilidade.

\footnotetext{
${ }^{5}$ Sobre emendamento constitucional especificamente, os autores salientam as dificuldades que o governo tem de aprovar uma reforma via emenda constitucional, por não contar com diversos recursos de interferência no processo legislativo disponíveis em outros tipos de votações, como o recurso da votação simbólica, pedido de urgência e o veto do poder executivo. O emendamento constitucional ainda trás dificuldades adicionais de aprovação, tal qual a exigência do quórum de 3/5 e a votação em dois turnos (Figueiredo e Limongi, 1999, pp. 193 a 223).
} 
Avançando na agenda de pesquisa sobre a relação entre a agenda de reformas dos últimos 22 anos de um lado, e o constitucionalismo brasileiro do outro, tendo como mediador o sistema político a teoria política tem se debruçado sobre o problema. Talvez em razão da atipicidade do caso brasileiro, foram produzidos avanços para além das teorias que relacionam emendamento constitucional diretamente às regras de emendamento, criando hipóteses sobre o que pode gerar demanda por emendamento da constituição. Atualmente, existem no mínimo duas teorias que procuram explicar o emendamento da constituição brasileira de 1988: a teoria do "contexto" e a teoria do "texto".

A teoria do contexto pode ser exemplificada a partir dos trabalhos de Souza (2008) e Melo (2007). Souza argumenta que as altas taxas de emendamento constitucional no Brasil estão relacionadas ao peculiar legado constituinte anacrônico de 1988, que tornou parte da constituição presa a um determinado contexto histórico, requerendo atualização. Para Souza, a explicação para as altas taxas de emendamento no Brasil não podem ser creditadas somente à regra de emendamento, mas também é preciso notar outras variáveis exógenas às instituições, notadamente o contexto econômico nos anos 90, para explicar porque a carta brasileira foi tão alterada. "Isso mostra que não apenas as regras, como afirma parte da literatura sobre emendas constitucionais, mas também as mudanças de contextos/conjunturas explicam as alterações constitucionais. Assim, os contextos político e macroeconômico mostraram, no caso do Brasil, ter importância equivalente à das regras" (p. 815).

Isso implica em afirmar que o ímpeto reformista da constituição brasileira estaria relegado a determinadas situações contextuais limites, quando houver grandes pressões por reformismo da relação entre Estado e economia. Na história recente, essa situação caracterizaria mais adequadamente o governo FHC, e não o governo Lula, que apenas deu continuidade às reformas realizadas. Portanto, o número de emendas constitucionais por ano teria arrefecido no governo Lula, tendo sido forte apenas no seu primeiro ano, quando foram completadas as reformas fiscais e macroeconômicas iniciadas no governo anterior. Nesse sentido, Souza (2008, p. 805) afirma que "as reformas constitucionais, iniciadas em 1992, tomaram ímpeto entre os cinco e os quinze anos após a promulgação da constituição, diminuindo consideravelmente após esses anos”.

Melo (2007) chega à mesma conclusão sobre o arrefecimento reformista a partir do início dos anos 2000, porém atribui o resultado não diretamente ao contexto econômico, mas a dificuldades do Presidente Lula manter uma coalizão tão unida e 
ideologicamente coerente quanto o governo FHC, discutindo as dificuldades de governabilidade impostas pelo modelo constitucional brasileiro dentro da teoria do presidencialismo de coalizão. Para este autor, governar no marco "hiperconstitucional" brasileiro implica custos, mas a constituição em si não é um fator de paralisia no processo decisório, ficando este sujeito à capacidade do Executivo de formar coalizões e impor sua agenda. Na síntese do argumento contextualista de Melo (2007), concluindo pela diminuição no ritmo de emendamento durante o governo Lula, fica clara a relação entre formação de coalizão como condição necessária para a produção, assim como sustentação, de uma agenda de reformas. "No caso do governo Lula, um padrão explicitamente não reformista passou a caracterizar a ação do governo. Não há uma agenda de reformas. E isso não por impedimentos e resistências, mas por problemas de gerenciamento da coalizão de governo e pelo estilo de liderança presidencial” (p. 260).

Melo também faz referências à falta de uma agenda política própria do governo Lula, que o levaria a reformas no marco constitucional. Porém, ele não chega a traçar uma relação causal entre agenda macroeconômica e emendamento constitucional, como faz Souza (2008). Isso ocorre porque os dois autores possuem teorias distintas para a formação da agenda de reformas, que traria emendas à constituição. Para Souza (2008) a formação da agenda é muito mais estrutural, e ditada por choques econômicos externos aos atores, fruto da combinação de uma constituição originalmente anacrônica em um cenário de profundas mudanças “neoliberais”. Para Melo (2007), a formação de agenda é contingente aos próprios atores, e ao grau de coerência da coalizão partidária que dá sustentação ao governo. Por isso que o "excesso" de agenda é o que causa altas taxas de emendamento durante o governo FHC e nos primeiros anos do governo Lula (Souza 2008); e que a "falta" de uma agenda distinta da anterior é o que causa o arrefecimento do ímpeto reformista nos anos 2000 (Melo 2007).

É possível chegar ao mesmo tipo de teorização analisando o trabalho de Arretche (2009), que tangencia o tema da relação entre sistema político brasileiro e emendamento da Constituição de 1988. Em seu trabalho, Arretche entretém a hipótese de que a Constituição brasileira de 1988 na realidade facilitou, e não dificultou as reformas pós-1988 que lidavam com a redistribuição de recursos na federação. Entre outras coisas, a autora pesquisou as votações de parlamentares nas propostas de emenda constitucional em matéria federativa, e descobriu que os congressistas se dividem em linhas partidárias, alinhados ao governo ou à oposição, e não de acordo com seu Estado de origem, e que as reformas realizadas ocorreram em detrimento do interesse dos 
Estados. Longe, portanto, de constituir um veto gate no sistema político brasileiro, a Constituição serviu como um instrumento para o governo federal impor às unidades federadas uma reorganização da distribuição de receitas.

O argumento de Melo e Souza é similar em sustentar que razões não institucionais podem ajudar a explicar a alta taxa de emendamento da constituição brasileira. Essas razões seriam contextuais e complementares, relacionadas à agenda política dos atores e às condições macroeconômicas do país. Para Souza, a taxa de emendamento da constituição de 1988 teria se mantido "artificialmente" alta em razão das reformas econômicas necessárias e implementadas durante a segunda metade da década de 90. Para Melo, as taxas de emendamento da constituição teriam arrefecido durante o governo Lula, principalmente em razão de problemas de gerenciamento da coalizão.

As previsões dos dois autores acerca do arrefecimento do emendamento constitucional não restaram comprovadas nem se considerarmos emendamento constitucional como número de dispositivos/tempo (Arantes e Couto 2009 e 2010), ou ainda emendas/anos ${ }^{6}$. Mesmo assim, a problematização sobre o impacto do contexto macroeconômico e da formação da coalizão vai ao centro do nosso problema sobre a relação entre sistema político e emendamento constitucional. Particularmente em Melo, relacionar reformas constitucionais e problemas de gerenciamento de uma coalizão heterogênea nos leva um passo adiante para pensar hipóteses sobre o impacto do sistema político brasileiro no emendamento da Constituição de 1988.

As conclusões e mecanismos explicativos de Melo (2007) e Souza (2008) são distintos dos de Arantes e Couto, porém as bases teóricas não são excludentes. Para Melo, existe uma relação entre formação de coalizão e emendamento constitucional. Arantes e Couto também percebem que a formação de coalizões que contem com maiorias qualificadas estáveis é condição necessária para o emendamento constitucional (Arantes e Couto 2009, p. 23). Além disso, o próprio processo de constitucionalização de políticas públicas pelo constituinte pode ter sido fruto de uma dinâmica de trocatroca típica de uma maioria com baixo grau de coerência partidária (Couto e Arantes 2006, p. 44). Para Souza (2008), a relação entre a constituição de 1988 e o contexto macroeconômico dos anos 90 é o que impulsionou o emendamento constitucional. Também para Arantes e Couto (2006), o legado constituinte de 1988, que produziu uma carta eivada de políticas públicas, é a razão do seu emendamento.

\footnotetext{
${ }^{6}$ Para mais detalhes sobre problemas em medir Constituições, ver apêndice metodológico.
} 
A diferença é que a explicação de Arantes e Couto, a qual denominei textual, transforma o próprio texto da constituição em uma matriz relacional que cria incentivos para diferentes governos se submeterem aos quóruns qualificados e governarem no marco constitucional. Na teoria da demanda produzida por Arantes e Couto, a constituição é uma instituição política com potencial de explicação do comportamento dos atores que se empenham pelo seu emendamento, sendo capaz assim de constituir-se como variável independente numa teoria do emendamento constitucional. Nessa perspectiva, as reformas constitucionais não estarão circunscritas a contextos específicos, mas serão condição para - e resultado - da capacidade do sistema político produzir decisões.

Porém, existe um limite cognitivo entre o tipo de mecanismo gerador de demanda por emendamento constitucional, tal qual explicado por Arantes e Couto, e a classificação entre policy e polity criada por eles. Para os autores, existem dois tipos de políticas públicas no Brasil: aquelas que estão na constituição e aquelas que não estão. O fato de existirem policies no texto constitucional cria incentivos adicionais para emendar a Constituição, e ao mesmo tempo também cria dificuldades adicionais para alterar as políticas que foram constitucionalizadas. Contudo, tratar da mesma maneira todas as políticas públicas que foram constitucionalizadas entre si, e também, por dedução lógica, em relação àquelas políticas públicas que não foram constitucionalizadas, ignora o fato de existirem diferentes mecanismos de mudança (ou continuidade) operando em relação às diferentes políticas públicas. $\mathrm{O}$ fato de uma política pública estar constitucionalizada não significa, de per se, que ela é mais difícil de ser alterada do que uma política pública que não esteja constitucionalizada, afinal, políticas públicas criam incentivos próprios para a sua manutenção ou mudança, independente do contexto institucional ${ }^{7}$.

A classificação entre polity e policy de Arantes e Couto consegue distinguir dispositivos constitucionais que produzem incentivos para serem alterados no curto prazo, daqueles "realmente" constitucionais, conectando as agendas de governos ao texto constitucional. Porém, entre as policies (constitucionalizadas ou não), podem existir ainda diferentes mecanismos operando em favor da continuidade ou mudança. Um passo adicional para entender como e em que medida as policies

\footnotetext{
${ }^{7}$ Me refiro ao fato de existirem explicações para a manutenção de uma política pública ou instituição, tais como aquelas feitas através de mecanismos de feedback positivos e de dependência da trajetória, que não se limitam a causas puramente institucionais, mas sim aos efeitos das políticas criadas no comportamento dos atores (ver, por exemplo, Pierson, 2004).
} 
constitucionalizadas criam incentivos para a mudança constitucional seria entender quais são os incentivos para mudança $e / o u$ estabilidade criados por cada política pública que é sustentada por dispositivo constitucional.

Para ficar apenas em um exemplo do argumento, tomemos dois dispositivos classificados como policy por Arantes e Couto, e que, portanto, estão sujeitos ao mesmo tipo de incentivo para serem alterados no curto prazo, mas que na realidade refletem políticas as quais, na prática, sofrem pressões muito diferentes para serem reformuladas, e, portanto, os dispositivos constitucionais que as refletem também sofrem incentivos diferenciados para serem mudados. Refiro-me ao artigo 242, parágrafo $2^{\circ}$ da constituição federal de 1988; e ao artigo 192, parágrafo $3^{\circ}$ original da constituição federal de 1988. Senão vejamos:

“Art. 242, § 2. . O Colégio Pedro II, localizado na cidade do Rio de Janeiro, será mantido na órbita federal."

“Art. 192, § 3. (original). As taxas de juros reais, nelas incluídas comissões e quaisquer outras remunerações direta ou indiretamente referidas à concessão de crédito, não poderão ser superiores a doze por cento ao ano; a cobrança acima deste limite será conceituada como crime de usura, punido, em todas as suas modalidades, nos termos que a lei determinar."

É fácil imaginar que um limite à cobrança de juros dentro de um país capitalista e com boa parte de seu capital financeiro localizado em bancos privados produz uma coordenação tão forte e imediata dos agentes financeiros contra o dispositivo legal que sustenta a política, que a sua manutenção se torna tarefa bastante custosa para qualquer governo, independente se ele é uma lei ordinária, constitucional ou mesmo cláusula pétrea $^{8}$. Já o dispositivo que ordena a manutenção da administração de um único colégio público pelo governo federal, ao invés do Estadual ou Municipal, gera pouca ou nenhuma pressão política para a sua alteração, e ele poderia muito bem permanecer como está mesmo se fosse regulado num simples ato administrativo. Tratar os dois dispositivos constitucionais da mesma maneira é ignorar as dinâmicas internas às políticas por eles reguladas, que produzem maiores pressões por estabilidade ou mudança.

\footnotetext{
${ }^{8}$ De fato, a limitação constitucional aos juros reais nunca entrou em funcionamento no Brasil. No início, os governos simplesmente a ignoraram, dadas as pressões inflacionárias e a posterior estabilização monetária baseada na âncora cambial. Logo em 1991, porém, o Supremo Tribunal Federal julgou que esse dispositivo não tinha aplicabilidade imediata. Ver ADI 4/DF de 1991. Com a aprovação da emenda 40, o dispositivo foi retirado do texto constitucional.
} 
De qualquer maneira, o argumento dos autores permanece, coeteris paribus os feedbacks produzidos por cada uma das políticas associadas às policies constitucionalizadas. O fato é que a constitucionalização dos detalhes de uma política pública ao mesmo tempo atrai para o texto constitucional a dinâmica ordinária de governar, e cria custos diferenciados para a mudança de uma política, uma vez que ela seja colocada em pauta.

Mas qual é essa dinâmica ordinária de governar no marco constitucional e qual o seu impacto para o texto da própria constituição? A hipótese de Arantes e Couto que atribui às políticas públicas constitucionalizadas em 1988 a própria razão do revisionismo constitucional não explica o fato que eles próprios identificaram, relativo a novos dispositivos de policies sendo constitucionalizados. Contrária a percepção de que o reformismo constitucional vinha desconstitucionalizando direitos (ver, por exemplo, Melo 2007), Arantes e Couto descobriram que a carta original cresceu em $28 \%$ entre 1988 e 2009, dos quais $70 \%$ dos novos dispositivos tratam de políticas públicas (Arantes e Couto 2009, p. 44).

De um lado, autores reforçam a capacidade de Executivos institucionalmente poderosos responderem a contextos de reformas e de crises localizadas, através de uma hábil formação de coalizão congressual que ultrapassa o limiar do emendamento com facilidade, e ressaltam que uma Constituição detalhada não oferece empecilho algum para governar, e de fato pode até mesmo reforçar o poder central em detrimento das periferias da federação (Melo 2007, Souza 2008, Arretche 2009). A Constituição e seu emendamento seriam, portanto, criaturas da União, em detrimento dos Estados, e do Poder Executivo em detrimento do Poder Legislativo.

Do outro lado, autores criticam os custos de governar impostos por ter uma Constituição bastante detalhada, e a distorção da maioria nas urnas que a constante necessidade de precisar atingir o quórum constitucional cria, mesmo em temas que não suscitam problemas de tirania da maioria, e portanto não precisariam da proteção adicional (Arantes e Couto 2010). Nessa perspectiva, a Constituição e seu emendamento seriam produto do Poder Legislativo, que através da Carta podem exercer pressão adicional no Poder Executivo, e obter dele garantias e restrições adicionais a mudanças em políticas públicas que se encontram asseguradas no texto da Constituição.

Dessas duas visões, duas hipóteses surgem para tentar explicar o contínuo aumento do texto constitucional: 
1) Hipótese da preponderância do Poder Executivo: O Poder Executivo prepondera sobre a arena legislativa, e a constitucionalização de mais dispositivos veiculadores de policy é fruto da ação de governos os quais, em razão da facilidade de aprovarem matéria legislativa, procuram salvaguardar suas preferências por políticas no texto da Constituição. Essa hipótese pode ser derivada dos trabalhos que salientam o sucesso do Poder Executivo na arena Legislativa, mesmo enfrentando o quórum qualificado para emendar a constituição. Tratando especificamente do emendamento constitucional, trabalhos como o de Melo (2007), Souza (2008) e Arretche (2009), já discutidos, salientam a facilidade de aprovação de uma emenda constitucional, desde que o governo tenha tido sucesso em montar uma coalizão parlamentar.

2) Hipótese da negociação legislativa: Governos são obrigados a governarem no marco constitucional brasileiro em razão do detalhamento original da constituição. Contudo, ao tentar aprovar uma reforma constitucional, é necessário negociar com a base parlamentar, a qual por sua vez exige concessões, alterações e garantias a serem oferecidas no texto da emenda constitucional, o que leva à proposta de emenda original a crescer em tamanho e detalhamento. 


\section{GOVERNANDO PARA ALÉM DO MANDATO OU NEGOCIANDO NO LEGISLATIVO?}

Antes de testar a duas hipóteses construídas no capítulo anterior, contudo, é necessário enfrentar algumas questões teórico-metodológicos presentes nas teorias sobre o emendamento constitucional. Essas questões dizem respeito à como é possível medir Constituições, e suas mudanças ao longo do tempo.

\subsection{A unidade de análise: como medir textos e mudanças constitucionais}

Do que estamos falando ao utilizar o termo "mudança constitucional" ou "emendamento constitucional”? O próprio termo "emendamento constitucional" precisa ser melhor definido, pois os trabalhos da área empregam diferentes nomes para o mesmo fenômeno, ou para fenômenos muito parecidos.

Elkins, Ginsburg e Melton (2009) utilizam o termo "mudança constitucional" (constitutional change) em seu estudo sobre a durabilidade (endurance) das Constituições nacionais. O foco principal do estudo desses autores é explicar por que Constituições nacionais morrem. Nesse contexto, o termo "mudança constitucional" é utilizado de forma a caracterizar tanto processos de emendamento de Constituições em vigência, quanto de mudança pela morte da Constituição existente, seja por suspensão da sua vigência ou pela substituição por uma nova. Essa distinção é conceituada quando os autores falam em "mudanças intra-constitucionais versus mudanças extraconstitucionais" (p. 74 a 76), ou ainda em "emendamento constitucional versus substituição constitucional” (p. 55 a 59). "Nós chamamos uma mudança constitucional de 'emenda' quando os atores afirmam seguir o processo de emendamento da Constituição existente para alterar o texto constitucional, e substituição constitucional quando o fazem sem invocá-lo" (Elkins, Ginsburg e Melton 2009, p. 55). Os autores focam principalmente a mudança constitucional por substituição, porém o nosso interesse aqui é no que eles denominam mudança constitucional por emendamento.

Emendamento constitucional, tal como definido no parágrafo anterior, por sua vez também engloba dois processos diferentes: o emendamento feito seguindo as regras estabelecidas na própria Constituição, que altera as palavras do texto constitucional, e a mudança feita por interpretação das palavras existentes na Constituição, alterando o seu sentido e aplicação. O primeiro método é comumente utilizado por parlamentos e governos, por vezes recorrendo-se a referendos, e ao segundo chama-se a atenção 
tipicamente em casos que envolvem interpretações da Constituição, feitas por Poderes Judiciários ou por Cortes Constitucionais. Em geral, denomina-se o primeiro tipo de "emendamento formal" e o segundo de "emendamento informal". Senão vejamos outro exemplo tirado de Elkins, Ginsburg e Melton (p. 74): "Dentro da barganha existente, existem dois mecanismos principais pelos quais a mudança constitucional ocorre: emendamentos formais ao texto e emendamentos informais que resultam de mudanças interpretativas (tipicamente, porém não exclusivamente, facilitado pelos Tribunais)". Prefiro restringir as mudanças interpretativas de uma Constituição àquelas dadas pelo Poder Judiciário, pois nos lugares onde existe judicial review, espera-se que a última palavra sobre o significado do texto constitucional em vigência seja dada por instâncias ligadas ao Poder Judiciário. Além disso, é muito difícil identificar objetivamente outros tipos de mudanças constitucionais por interpretação, assim como as causas ou atores que levariam a elas. Para Lutz, existem quatro tipos de "mudança constitucional". 1) O processo formal de emendamento; 2) substituição completa da Constituição por uma nova; 3) revisão judicial; e 4) revisão legislativa. Mesmo a mudança por "interpretação parlamentar”, apesar de ser possível identificar o ator responsável, ainda assim é difícil determinar quando se constituiria uma mudança do texto constitucional por “interpretação parlamentar".

Prefiro denominar de emendamento constitucional e mudança constitucional por interpretação judicial aos dois processos. A diferença está no processo decisório, nos atores envolvidos e na relação entre as duas coisas. Não apenas os atores e a maneira de decidir é bastante distinta entre poderes legislativos e tribunais constitucionais, mas o processo de interpretação constitucional está axiologicamente sujeito àquilo que está estabelecido no texto formal, e até por isso mesmo uma emenda constitucional pode reverter uma decisão judicial, com exceção de sistemas nos quais quem tem a última palavra sobre a constitucionalidade da emenda é o próprio judiciário. Os tribunais constitucionais podem ainda ter interpretações bastante inovadoras, cuja ligação com o texto em si exige, no mínimo, um exercício de criatividade por parte do lei. A própria criação do instituto da revisão judicial em 1803 nos EUA foi algo feito ao arrepio do texto existente ${ }^{9}$.

\footnotetext{
${ }^{9}$ No conhecido caso Marbury VS. Madison (1803). Na Índia também o poder de rever a constitucionalidade de emendas constitucionais foi inventado pela Supreme Court of India a despeito do que dizia o texto constitucional e da vontade do próprio parlamento, que se manifestou contra essa possibilidade via emenda constitucional (Emenda 42 à Constituição da Índia). Ver: Minerva Mills Ltd. and Others Vs. Union of India and Others (1980) 2 S.C.C. 591.
} 
Por fim, há os termos "reforma constitucional" e "revisão constitucional", que por vezes são utilizados de maneira intercambiável, e transitam entre o emendamento constitucional e uma substituição completa da Constituição existente. Reforma constitucional em geral é utilizado em situações nas quais ocorre um emendamento constitucional, porém o resultado é tão amplo que se chega até mesmo a criar uma dúvida se ainda é possível falar da mesma Constituição, ou trata-se de uma nova carta (exemplos são a reforma constitucional de 1969 à Constituição brasileira de 1967, e as reformas à Constituição da Argentina). Revisão constitucional é um termo mais utilizado quando existe um marco ou exigência temporal ao emendamento constitucional, o qual pode ser realizado nesse momento, em geral, segundo regras mais flexíveis, supondo-se que de tempos em tempos é necessária uma revisão mais ampla do pacto constitucional (exemplos são a reforma constitucional brasileira de 1993 e as reformas à Constituição portuguesa de 1976, que neste último caso estão programadas para ocorrerem de cinco em cinco anos).

Não irei utilizar essa nomenclatura por três razões. Primeiro, ela é pouco precisa: O que constitui uma emenda abrangente o suficiente para ser denominada "reforma"? O que caracteriza uma "revisão" constitucional? O fato de ela ter uma exigência temporal ou o fato de possuir um quórum específico de aprovação? Segundo, não há significado em diferenciar "revisões" de "emendas constitucionais", senão quantificar o impacto de uma regra peculiar de emendamento constitucional no seu texto, caso no qual a "revisão" ou "reforma" constitucional podem ser absorvidos por uma teoria acerca do impacto das regras de emendamento no texto da Constituição ${ }^{10}$. E por fim, existem situações denominadas "reformas" que se referem a contextos excepcionais nos quais nem sempre as regras foram pré-estabelecidas ou sequer estão na Constituição, casos nos quais se torna infrutífero testar hipóteses institucionalistas sobre o impacto das regras de emendamento.

Essa distinção de termos é importante, pois cada um trata de uma dinâmica independente, mas teoriza-se bastante sobre o seu impacto recíproco. Para Lutz (1994 p. 358), quão mais longeva uma Constituição que, no entanto, possui baixa taxa de emendamento $^{11}$, maiores as probabilidades de o processo de mudança constitucional estar ocorrendo por outra via, presumivelmente uma Corte Constitucional, como seria o

\footnotetext{
${ }^{10}$ Lutz (2006) também descarta o termo "revisões" por entendê-lo pouco preciso (p. 152).

${ }^{11}$ Uma explicação sobre o conceito de "taxa de emendamento" será dada a seguir.
} 
caso da norte-americana ${ }^{12}$. Elkins, Ginsburg e Melton (2009) testam a hipótese, mas não encontram uma correlação entre a presença de Cortes Constitucionais e sobrevida constitucional. Ambos os estudos, porém, prevêem que baixo emendamento constitucional está relacionado ao fim das Constituições. Por trás dessa previsão está a idéia de que mudanças são inevitáveis, seja pela impossibilidade de prever completamente o funcionamento das instituições até elas serem efetivamente postas em prática, ou ainda porque novas situações completamente imprevistas podem surgir e exigir uma nova acomodação estrutural a ser expressa na Constituição.

Teorizando sobre como diferentes arranjos constitucionais lidam com essa mudança inexorável, Elkins, Ginsburg e Melton (2009) encontram correlações entre a durabilidade de uma Constituição e seu nível de inclusividade, detalhamento e facilidade de emendamento. Para os autores, uma Constituição mais parecida com uma grande lei ordinária tende a durar mais, porém essa correlação é curvilínea, e cada uma dessas variáveis em excesso pode contribuir para o fim de uma Constituição ou simplesmente para que ela deixe de funcionar como tal (ver, por exemplo, p. 100).

\subsection{Medindo Constituições}

As próprias questões conceituais envolvidas nos estudos sobre mudanças constitucionais escondem problemas abordados pelas teorias. Qual a relação entre o emendamento constitucional e a morte de uma Constituição? Qual a relação entre emendamento das Constituições e a mudança por interpretação judicial? Em razão dessas questões empíricas e dos problemas teóricos abordados, se tornou cada vez mais importante para a compreensão da mudança constitucional precisar o impacto das regras no emendamento do texto constitucional.

Mas como medir o emendamento de uma Constituição? O conceito chave trabalhado pela literatura é o de "taxa de emendamento". Em geral, entende-se por "taxa de emendamento" o número de emendas constitucionais aprovadas ao longo do tempo, e a variável "tempo", por sua vez, costuma ser medida em "anos" (Lutz 2006, Lorenz 2005, Elkins, Ginsburg e Melton 2009, Melo 2007). Essa maneira de medir o emendamento de uma Constituição salienta os custos políticos fixos envolvidos na aprovação de uma emenda, e não exatamente o quanto determinado texto constitucional foi alterado por efeito do seu emendamento. Mais precisamente, número de emendas

\footnotetext{
${ }^{12}$ Em Lutz, o exemplo aparece de maneira idiossincrática para tentar explicar o caso americano como
} outlier. 
constitucionais ao longo do tempo mede quantas vezes os atores políticos com acesso ao texto constitucional conseguiram ultrapassar as barreiras e exigências procedimentais para alterar o seu conteúdo, e não o quanto efetivamente o seu conteúdo foi alterado em razão das emendas realizadas. Para tanto, seria necessária uma quantificação que tomasse o próprio conteúdo da Constituição como objeto.

Existem outras medidas que quantificaram o conteúdo dos textos constitucionais e que, portanto, podem ser utilizadas para avaliar o quanto o texto de uma Constituição foi alterado ao longo do tempo. Contudo, não se utiliza o termo "taxa de emendamento" para falar dessas medidas, apesar de que, de certa maneira, elas também medem a "taxa de emendamento" de uma Constituição, no sentido de que avaliam mudanças constitucionais ao longo do tempo.

O próprio Lutz (2006, p. 156) aponta em seu trabalho que "Quão maior o número de funções governamentais tratadas na Constituição, tão maior ela será e maior também será a sua taxa de emendamento". Ou seja, é possível, em teoria, comparar quantas funções governamentais uma Constituição tinha ou passou a ter ao longo do tempo, determinando a sua "taxa de emendamento" de acordo com o número de funções governamentais presentes no texto constitucional. Lutz, contudo, não propõe uma quantificação dessa variável, encapsulando-a na sua outra variável, a qual propõe também afetar positivamente a sua taxa de emendamento constitucional (emendas/ano): o número de palavras. Dessa maneira, "funções governamentais" e "número de palavras" são tratadas como uma coisa só em seu modelo: agregam mais elementos à carta, tornando-a mais extensa sem, contudo, que haja uma qualificação destes elementos capaz de discernir sua importância ou sua capacidade de produzir efeitos políticos diferenciados.

Ou seja, no modelo de Lutz, "taxa de emendamento constitucional” (número de emendas/ano) é tratada como variável dependente a ser parcialmente explicada pela variável independente "número de palavras" (que também incorpora a noção de número de funções governamentais). Porém, é possível tratar "número de palavras" como a variável dependente, indicativa do quanto uma Constituição foi alterada (cresceu ou diminuiu de tamanho) ao longo do tempo, ou do quanto duas ou mais Constituições são diferentes entre si em tamanho ${ }^{13}$.

\footnotetext{
${ }^{13}$ Melo (2007), por exemplo, faz esse exercício, tentando aplicar o modelo de Lutz ao caso brasileiro.
} 
Elkins, Ginsburg e Melton (2009) propõem uma quantificação diferenciada para aquilo que Lutz denominaria "funções governamentais". Além de medir "detalhamento constitucional" também como número de palavras (seguindo a idéia de Lutz), Elkins, Ginsburg e Melton elegeram uma lista prévia de 92 tópicos que podem ou não ser tratados por um texto constitucional (medida binária), para tentar medir a sua abrangência ou escopo, o que torna possível comparar textos constitucionais quanto à sua similaridade entre si, em relação a esses 92 tópicos. Ao escolher “tópicos”, contudo, os autores enfrentam o problema de o que considerar como um tópico por si só e o que pode ser absorvido num tópico maior, ou, como eles mesmo colocam o problema, "A esse respeito, nós enfrentamos uma tarefa delicada de selecionar os atributos com os quais construir a medida. Outra escolha relacionada envolve se perguntar quão fundo na cadeia decisória devemos ir”(Elkins, Ginsrbug e Melton, 2009, p. 24). Um exemplo dado pelos próprios autores pode ser ilustrativo dos problemas envolvidos nessa quantificação: ao considerar o método de eleição para a Câmara dos Deputados (se majoritário ou proporcional) como um tópico a ser contabilizado, eles deixam de fora detalhes sobre o mecanismo específico de seleção dos membros dessa câmara (magnitude dos distritos, fórmula matemática de transformação de votos em cadeiras, cláusulas de barreira, etc). Outro exemplo é o fato de os autores contabilizarem como um tópico a presença ou ausência de poder de veto para o Executivo, porém deixarem de fora a modalidade de veto que possa existir (se inclui veto parcial ou apenas o veto total, por exemplo). A classificação, portanto, descarta outras matérias que possam vir a ser objeto do texto.

Por fim, Arantes e Couto (2006, 2008, 2009 e 2010) desenvolveram um modelo que decompõe textos constitucionais em "dispositivos". Nesse modelo, não se contabilizam número de palavras ou tópicos constitucionais, mas dispositivos. Cada dispositivo se refere, grosso modo, a um comando legal existente no texto de uma Constituição. Além disso, o modelo de Arantes e Couto incorpora uma classificação adicional que qualifica os dispositivos como polity ou policy. Por polity entende-se matéria sob a qual é possível supor alto nível de consenso, tratando de definições de Estado e cidadania, regras gerais de interação entre os poderes, direitos civis e políticos fundamentais, ou direitos materiais básicos; já as policies são disposições que, conquanto constitucionalizadas, fazem parte da disputa político-partidária ordinária, e estão sujeitas a pressões por mudanças no curto prazo, podendo-se esperar que governos procurem alterá-las com frequência. As hipóteses subjacentes ao modelo de Arantes e 
Couto são as de que: 1) uma Carta com mais dispositivos tende, no longo prazo, a ser mais emendada (mesma lógica por trás da noção de uma carta com muitas palavras); e 2) uma Carta com maior quantidade de policies - políticas públicas específicas, objeto da controvérsia partidária ordinária - apresenta tendência adicional a ser mais emendada ao longo do tempo, inclusive no curto prazo. Constituições detalhadas, para Arantes e Couto, não são necessariamente Constituições longas, mas Cartas que possuem mais policies. Retornarei ao modelo de Arantes e Couto mais adiante e também no próximo capítulo, inclusive para explicar melhor a distinção feita entre polity e policy.

Apesar de a lógica subjacente à contabilização de palavras, tópicos ou dispositivos ser a mesma - Constituições mais longas, incorporam mais aspectos da vida política e tendem a ser mais alteradas -, considerar diferentemente tamanho de Constituição como palavras, tópicos ou dispositivos pode resultar em análises bastante distintas. Melo (2007, p. 240), por exemplo, propõe que uma Constituição com muitas palavras é necessariamente uma Carta detalhada, e ranqueia a Constituição Brasileira de 1988 (32 mil palavras) atrás da portuguesa, 1976 (41 mil palavras) e bem atrás da indiana, 1949 (137 mil palavras). Utilizando a Metodologia de Análise Constitucional (MAC) de Couto e Arantes, no entanto, a Carta brasileira (1.627 dispositivos) ultrapassa a portuguesa (943 dispositivos) e está bastante próxima da indiana (1656 dispositivos) em tamanho, com o acréscimo de que a Constituição brasileira (496 policies) é bem mais "detalhada" do que a indiana ( 83 policies) e a portuguesa (42 policies) ${ }^{14}$.

A pergunta: "como medir Constituições?" suscita, portanto, pelo menos quatro diferentes respostas que afetam tanto o enfoque da análise realizada, quanto os seus resultados: a primeira, mais comum, é normalmente atrelada ao conceito de "taxa de emendamento", e significa contabilizar o número de emendas constitucionais por ano; a segunda implica em medir o número de palavras ou linhas (ou letras, ou toques, etc.) de uma Constituição, e é indicativa de sua extensão e/ou detalhamento; a terceira propõe que se contabilizem "tópicos" constitucionais, medindo o quanto uma determinada carta contempla de aspectos pré-selecionados de uma lista; e a quarta, por último, propõe que se contabilizem "dispositivos", capazes de medir, ao mesmo tempo, extensão e perfil de uma Constituição.

A primeira maneira de medir mudança constitucional está atrelada às teorias de rigidez constitucional. Como vimos, ela não mede exatamente o quanto o texto de uma

\footnotetext{
${ }^{14}$ Fonte: Arantes e Couto 2006 e, sobre Índia e Portugal, elaboração própria. Em todos os casos excluemse os Atos e Disposições Constitucionais Transitórias. Projeto Constitucionalismo e Democracia em Perspectiva Comparada.
} 
Constituição mudou, mas quantas vezes os custos institucionais para tal mudança foram ultrapassados com sucesso. Já a segunda maneira de medir Constituições, através de palavras, de fato constitui um método comparativo capaz de aferir diferenças entre Constituições no que diz respeito ao seu tamanho. Porém, além dos problemas que podem aparecer em comparar diferentes línguas ou maneiras de se escrever uma Constituição em diferentes países, trata-se de um método praticamente sem orientação teórica alguma, que diz muito pouco sobre o conteúdo da mudança. A terceira maneira de medir Constituições, seguindo uma classificação em tópicos, consegue fazer distinções teóricas dentro dos textos constitucionais, e quantificá-los segundo idéias gerais presentes na tradição da teoria política e do constitucionalismo sobre as coisas que geralmente constam em textos constitucionais (forma de governo, forma de Estado, diferentes direitos individuais ou materiais, relações entre os poderes, etc). Ela também possui capacidade comparativa, que, no caso do modelo de Elkins, Ginsburg e Melton, é mais bem sucedida em medir grandes mudanças constitucionais, justamente porque os "tópicos" são bastante gerais, e menos bem sucedida em avaliar mudanças mais pontuais em um mesmo texto. A estratégia de uma lista pré-codificada de "tópicos", contudo, pode ser criticada por deixar de lado todos os demais aspectos que uma Constituição pode conter. Sua definição é feita, basicamente, segundo aquilo que seus proponentes consideram importante destacar nos textos constitucionais, não existindo ademais justificativas teóricas para determinar porque certos tópicos foram contemplados na tipologia e outros não. Por fim, a classificação em dispositivos oferece um critério ao mesmo tempo objetivo e teoricamente orientado para quantificar e qualificar textos constitucionais. A definição em dispositivos possibilita a decomposição de um texto constitucional em unidades objetivas o suficiente para tornar possível a comparação, ao longo do tempo, das alterações feitas em determinado texto constitucional, dispositivo a dispositivo. Além disso, a Metodologia de Análise Constitucional (MAC) de Arantes e Couto oferece critérios substantivos comparativos gerais e precisos para qualificar os dispositivos de textos constitucionais não apenas como polity ou policy - identificando incentivos para mudança constitucional de curto prazo presentes no próprio texto da Constituição - mas também se o dispositivo se refere a definições de Estado e Nação; regras do jogo; direitos individuais fundamentais; ou direitos materiais. 


\subsection{O impacto do processo legislativo na Constituição de 1988}

O quanto do emendamento da Constituição brasileira de 1988 pode ser creditado a iniciativas do Poder Executivo e o quanto é resultado da negociação parlamentar na arena legislativa? Quanto cada fase do processo legislativo contribuiu para a definição do texto final de cada emenda? Quanto restou das PECs inicialmente introduzidas nos textos finalmente levados à promulgação? Qual das duas casas legislativas é a maior responsável pelo texto finalmente aprovado? Em que medida a necessidade de duas votações em cada casa legislativa efetivamente influencia no texto das emendas? Aonde se define o texto final de uma emenda constitucional e quem pauta aquilo que finalmente vai parar no texto da Carta? Será no plenário das casas legislativas ou nas comissões que apreciam as PECs que finalmente se produzem os consensos em relação ao texto final?

Para responder a essas perguntas, utilizei a Metodologia de Análise Constitucional (MAC) ${ }^{15}$ para quantificar o texto de todas as 67 PECs apresentadas ${ }^{16} \mathrm{e}$ finalmente promulgadas, assim como as versões dessas PECs que foram sendo aprovadas em cada uma das fases do processo legislativo. Cada etapa institucional por onde necessariamente deve passar uma PEC produz consensos e, em tese, cria custos para alterações futuras, mas não se sabe exatamente quais fases são mais relevantes para o resultado final.

É importante saber quais etapas impactam mais diretamente na definição de uma emenda, pois diferentes instâncias institucionais possuem diferentes regras e atores que podem afetar tanto o processo legislativo, quanto seu resultado. Por exemplo, sabe-se que, em geral, os plenários das duas Casas Congressuais são os fóruns primordiais nos quais se decidem as questões mais controversas que envolvem matéria legislativa, em razão do modus operandi do sistema político brasileiro desde a redemocratização (Figueiredo e Limongi 1995). Isso ocorre porque o poder terminativo das Comissões é eclipsado pelos poderes de agenda que habilitam o Poder Executivo a, direta ou indiretamente, trazer uma peça legislativa que está sendo discutida em Comissão diretamente para votação em plenário (Pereira e Muller 2000). Além disso, o Executivo pode influenciar a pauta do plenário das Casas seja através do uso de Medidas Provisórias, que têm prioridade de votação e podem trancar a pauta ordinária, ou movimentando a base aliada posicionada nas instâncias que decidem a legislação que

\footnotetext{
${ }^{15}$ Para maiores detalhes sobre o uso da MAC para medir textos constitucionais, ver apêndice metodológico, e também Couto e Arantes (2006) e Couto (2008).

${ }^{16}$ Excluindo as Propostas de Emenda de Revisão.
} 
será votada, além de questões regimentais que influenciam nas votações (Presidências, Mesas Diretoras e Colégios de Líderes). Dessa maneira, o governo, através de sua base aliada, possui capacidade tanto para impedir votações, quanto para acelerá-las. O mesmo efeito também pode ser atingido no caso das matérias legislativas de iniciativa privativa do Executivo, como é o importante caso das leis orçamentárias. Esse timing é essencial para otimizar o aproveitamento das coalizões, além de favorecer a construção de maiorias. Por fim, o governo ainda pode ameaçar o Congresso com futuros vetos parciais ou totais sobre peças legislativas que distem demasiadamente dos seus interesses.

No caso das emendas constitucionais, esses poderes de agenda em favor do Executivo são bastante reduzidos. Primeiro porque não é possível "pular" nenhuma das fases no processo legislativo de uma emenda ${ }^{17}$, nem fazê-la "subir na pauta" através de pedidos de urgência; segundo porque ameaças de veto não são possíveis em relação a emendas constitucionais, na medida em que não existe veto à emenda à Constituição; e terceiro, existe a questão do quórum diferenciado de aprovação, que aumenta os custos de manutenção da coalizão; além disso, existe o fato de que não é possível oferecer nova proposta de emenda acerca de matéria já rejeitada ou havida por prejudicada na mesma sessão legislativa (art. 60, $\S 5^{\circ}$ da Constituição Federal). O único instrumento constitucional que existe para o Executivo intervir diretamente no conteúdo de uma emenda é sua capacidade de oferecer, ele próprio, uma PEC. Esse, contudo, não é um instrumento a ser desconsiderado. Figueiredo, por exemplo, salienta as dificuldades do Executivo federal aprovar uma proposta conciliadora de reforma agrária em 1963, em razão da Constituição do período não lhe autorizar a proposição de proposta de emenda constitucional (Figueiredo 1993, p. 114 a 115)

Subsiste em favor da aprovação das PECs a dinâmica geral de funcionamento do Congresso Nacional, que está atrelada à formação de uma coalizão sustentável, um cartel legislativo patrocinado pelo Executivo, capaz de produzir consensos e aliar interesses de longo prazo entre diferentes partidos (Octavio Amorim Neto, Gary W. Cox e Mathew D. McCubbins 2003). O próprio fato de termos tido tantas emendas constitucionais aprovadas desde 1988, à despeito das particularidades das PECs dentro

\footnotetext{
${ }^{17}$ Apesar de isso ter ocorrido uma única vez, na emenda 20 (reforma da previdência de FHC), quando o governo se aproveitou da incapacidade de uma Comissão Especial, encarregada de analisar uma emenda constitucional, de produzir um relatório final no prazo em que devia deliberar. Na ocasião, essa paralisia na Comissão deu ensejo a uma manobra regimental que retirou a matéria da Comissão Especial e a trouxe direto à votação em plenário, onde foi possível construir uma coalizão capaz de aprovar e dar seguimento à PEC de interesse do governo. Para maiores detalhes, ver Limongi (1998).
} 
da dinâmica da coalizão descrita acima, é prova de que, uma vez formado, o cartel legislativo consegue produzir decisões à despeito da rigidez constitucional.

Porém, a mera evidência da aprovação de PECs não enfrenta questões de fundo, ligadas aos custos diferenciados das políticas constitucionalizadas, e às distorções à representação eleitoral que o processo de constitucionalização de políticas públicas reforça. Arantes e Couto (2010) colocam o problema da seguinte maneira: “O contínuo processo de aprovação de ECs não constitui evidência suficiente de que a constitucionalização de políticas públicas seja um falso problema. Tal constatação despreza a questão dos custos (...). Já no que diz respeito à representação democrática, seu comprometimento está relacionado primeiramente ao fato de que a constitucionalização de políticas públicas pode tornar inócuas ou pouco consequentes as escolhas feitas pelos eleitores nas urnas, pois, na medida em que se exigem supermaiorias para a tomada de decisões acerca de questões ordinárias que foram constitucionalizadas, a maioria eleita dependerá da anuência das minorias derrotadas para levar adiante suas políticas. Noutros termos, impede-se ao eleitor-cidadão de uma democracia que mude os rumos de um governo cujas decisões e ações recaem sobre ele próprio, pois esse mesmo governo é impotente para mudar o status quo, ou, ao menos, para mudá-lo seguindo a regra da maioria a um custo decisório normal em sociedades plurais. Um segundo fator de comprometimento da representação é o encarecimento do processo político mediante o reforço excessivo das minorias partidárias. Estas podem chantagear politicamente governos com maiorias parlamentares enfraquecidas por serem insuficientes para o encaminhamento de uma agenda que, apesar de ordinária, foi entrincheirada constitucionalmente".

Apesar de termos ultrapassado o problema da ingovernabilidade, uma melhor qualificação do impacto do sistema político brasileiro sobre a agenda política ainda é uma questão em aberto. Apesar do atual consenso na literatura sobre como os poderes de agenda, aliados à organização interna no Legislativo produzem governabilidade do sistema, atrelada à pauta do Executivo ${ }^{18}$, ainda há dissenso acerca de qual é exatamente o incentivo para os parlamentares individuais cooperarem com seus partidos, ou com o governo e como isso afeta a capacidade do Congresso Nacional atuar de maneira independente e de fato constituir um fórum político mais ou menos relevante dentro do processo decisório. Sabe-se que as políticas do Executivo levadas à votação nos

\footnotetext{
${ }^{18}$ Outras ferramentas explicativas importantes para o "presidencialismo de coalizão", conhecidas pela literatura, são o controle do Executivo sobre o orçamento e a distribuição das pastas ministeriais. Aqui, contudo, elas são menor importância, pois não afetam diretamente o processo legislativo.
} 
plenários das duas casas do Congresso Nacional raramente são rejeitadas e que o que melhor prevê a disciplina dos deputados é seu pertencimento (ou não) a partidos políticos ligados à base do governo, ou à oposição (Figueiredo e Limongi 1999).

Por outro lado, argumenta-se que existe uma agenda que nem mesmo chega a entrar na pauta congressual ou que, entrando, nunca é levada a plenário, pois o governo antevê sua derrota e decide não arcar com os custos de parecer fraco frente aos seus aliados na base (Ames 2003). Outros ainda alegam que a pauta do governo é diluída pela base aliada, em favor de "paroquialismos", seja porque o governo modula seu posicionamento em determinadas questões antes mesmo de passar a matéria para deliberação pelo Legislativo, antevendo críticas e rejeições potenciais, seja porque os próprios parlamentares fazem alterações àquilo que recebem do Executivo, durante a fase de deliberação parlamentar (Mainwaring 2001). De qualquer maneira, a dinâmica de funcionamento da coalizão forçaria o afastamento das políticas do núcleo de preferências do Executivo, e o sistema todo funcionaria de modo lento, incoerente e de maneira custosa.

Os estudos sobre processo legislativo e sistema político brasileiro evoluíram buscando avaliar e qualificar o que determina o comportamento do parlamentar brasileiro, produzindo uma enorme variedade de dados estatísticos relacionados às votações em plenário e sua ligação com a distribuição de cargos no Executivo. Porém, menor atenção tem sido dada aos resultados dessa interação entre Executivo e Legislativo, com exceção dos trabalhos sobre emendas parlamentares ao orçamento (Pereira e Muller 2002, Figueiredo e Limongi 2002, Souza 2003a, Arretche e Rodden 2004, Limongi e Figueiredo 2005), e do trabalho de Amorim Neto e Paulo Tafner sobre Medidas Provisórias (2002). Uma das minhas intenções com os dados empíricos sobre o impacto do processo legislativo no emendamento constitucional é justamente contribuir para suprir essa lacuna, entendendo exatamente qual o papel das duas casas do Poder Legislativo (se algum) no emendamento constitucional.

O quão importante de fato é o Legislativo na determinação do conteúdo de matérias que devem contar com sua anuência? Uma análise quantitativa do impacto do processo legislativo no emendamento constitucional pode responder essa pergunta com uma visão geral sobre os dispositivos que foram alterados ao longo da aprovação de uma PEC.

Para se tornar uma emenda à Constituição, uma PEC precisa necessariamente ser aprovada em duas votações em cada uma das Casas Legislativas, por uma maioria 
qualificada de 3/5 do total de membros de cada uma das Casas. Além disso, qualquer alteração feita pela Câmara federal ou pelo Senado necessariamente precisa de mútua anuência qualificada. Dentro de cada uma das Casas Legislativas, a tramitação de uma PEC está ainda sujeita aos respectivos Regimentos Internos, que submetem a deliberação da PEC à anuência prévia das respectivas comissões de Constituição, Justiça e de Cidadania, além de uma Comissão Especial, criada ad hoc para cada PEC durante sua passagem na Câmara dos Deputados, com o objetivo de avaliá-la. As deliberações dessas comissões estão sujeitas ao plenário das respectivas casas, porém, uma vez elaborados relatórios nessas comissões, esses relatórios têm precedência de votação sobre a PEC original e sobre eventuais substitutivos elaborados em plenário, dando-lhes vantagem sobre propostas e alterações que venham correndo em paralelo. Ademais, em tese, essas comissões servem como fóruns para formação de consensos dentro das casas Legislativas, prévio à deliberação dos plenários, aproveitando-se dos quóruns reduzidos. As PECs não são apreciadas pelas demais comissões temáticas do Congresso Nacional.

Outra importante questão metodológica ligada ao regimento interno que precisa ser compreendida neste momento trata do instituto da "tramitação em conjunto", ou "apensamento". Por esse instituto, resolvem-se problemas de preferência entre propostas legislativas (inclusive PECs), em tramitação no Congresso Nacional, e que tratem do mesmo tema.

Para ser aceita para deliberação em qualquer uma das casas do Congresso Nacional, uma PEC deve atender a pelo menos um dos três incisos do art. 60, caput, da Constituição Federal:

“Art. 60. A Constituição poderá ser emendada mediante proposta:

I- Do Presidente da República;

II - de um terço, no mínimo, dos membros da Câmara dos Deputados ou do Senado Federal;

III - de mais da metade das Assembléias Legislativas das unidades da Federação, manifestando-se, cada uma delas, pela maioria relativa de seus membros."

Uma vez recebida a PEC, ela deve ser encaminhada à CCJ da respectiva casa do Congresso Nacional, porém, se já existir uma PEC em tramitação sobre aquele mesmo tema, a nova PEC apresentada é apensada à existente, dando-se sempre preferência à 
PEC originada de outra casa congressual (o Senado dá preferência à PEC da Câmara, e a Câmara dá preferência à PEC do Senado, se ambas versarem sobre o mesmo tema). Essa solução de conflitos entre PECs do mesmo tema diz respeito apenas às PECs “ativas" no Congresso Nacional. PECs arquivadas, ou rejeitadas, não têm preferência sobre novas PECs, mesmo que versem sobre o mesmo tema.

Para avaliar o impacto de cada uma das fases deliberativas do Congresso Nacional na redação de uma PEC até a sua aprovação como emenda, utilizei da Metodologia de Análise Constitucional (MAC), dividindo o texto das PECs em dispositivos. Cada dispositivo representa, em geral, cada alínea, inciso, parágrafo ou artigo do texto constitucional. Além das PECs, também contabilizei os substitutivos à PEC inicial, avaliando dessa maneira as alterações feitas tanto nas comissões quanto nas votações em plenário nas duas Casas Legislativas. Dessa maneira, é possível saber quais dispositivos foram acrescentados às propostas originais, quais foram alterados e quais foram excluídos. Também é possível saber em qual fase cada um dos dispositivos que eventualmente foram incorporados na emenda à Constituição, ganharam sua redação final. Também identifico os dispositivos das PECs de acordo com sua origem (Câmara, Executivo, ou Senado).

Se de fato o Executivo prepondera sobre o Legislativo, é de se esperar que se encontrem muitos dispositivos originários do Executivo nas emendas promulgadas, ou pelo menos que aqueles dispositivos introduzidos pelo Executivo tenham passado incólumes pelo processo legislativo. Do contrário, se muitos dispositivos originários do Executivo tenham sido excluídos do texto final da emenda, e se, além disso, novos dispositivos tenham sido introduzidos ou alterados pelo Legislativo, é de se concluir que o impacto do Legislativo no emendamento da Constituição é relevante.

Antes de verificarmos os dados, contudo, dois problemas de interpretação são importantes de serem enfrentados neste momento. Primeiro, é sabido que à maioria Congressual cabem importantes prerrogativas institucionais dentro de cada uma das Casas, que por sua vez influenciam no conteúdo daquilo que é aprovado em todas as fases de deliberação pelas quais deve passar uma proposta legislativa. Também é sabido, conforme discutido anteriormente, que o Executivo possui papel fundamental na formação de qualquer maioria parlamentar.

Dentro dessa lógica de maiorias, a escolha da Presidência das comissões dentro das casas é feita dando-se prerrogativa aos partidos com maior número de parlamentares. Os Presidentes das comissões, por sua vez, possuem importantes 
prerrogativas institucionais, dentre elas, talvez a mais relevante para o nosso estudo, a capacidade de escolher os relatores das propostas sob o escrutínio da respectiva comissão. Os relatores são figuras-chave dentro de cada comissão, pois cabe a eles oferecer parecer sobre a PEC apresentada, podendo sugerir sua aprovação sem alterações, reprovação, ou aprovação de substitutivo, ou seja, uma versão alterada daquilo sobre o que a comissão deveria deliberar. Esse parecer é então votado pelo restante da comissão, que pode aprová-lo, rejeitá-lo, ou ainda aprovar novas alterações ao parecer do relator. Apesar de os pareceres dos relatores necessitarem serem referendados pela respectiva comissão, a capacidade de um relator direcionar a pauta daquilo que será discutido pela comissão não deve ser ignorada. Revoltar-se contra o parecer de um relator significa reunir maioria dentro da comissão, tarefa dificultada pelo fato de que o relator pode cooptar membros da comissão a seu favor, simplesmente incorporando demandas individuais dentro de seu relatório ${ }^{19}$.

Outra maneira de a maioria e do Executivo influenciarem na deliberação de uma PEC é controlando parcialmente a pauta dos plenários. Como já foi dito acima, o Executivo não pode, através de pedidos de urgência, "subir" determinada PEC na pauta legislativa, atropelando o trabalho das comissões. Porém, é possível retardar a votação de uma PEC que não esteja de acordo com a vontade do Executivo, simplesmente introduzindo Medidas Provisórias na pauta do plenário, pedindo urgência na votação de outras matérias legislativas, conclamando os parlamentares da base aliada a exercerem obstrução no plenário ou nas comissões (impedindo que seja atingido o quórum de deliberação) ou ainda através de influência sobre o Colégio de Líderes ou sobre as Presidências e Mesas das Casas em questões procedimentais. O Executivo, portanto, continuaria a determinar sua vontade e a manutenção de suas preferências através dos mecanismos políticos de formação da maioria, que por sua vez resolve uma série de problemas de agência dentro das Casas Legislativas, delegando funções de pauta importantes a atores majoritários.

Em razão de tudo isso, é possível argumentar que mesmo as alterações feitas pelo Legislativo são fruto da vontade do governo, que é o timoneiro da maioria congressual, e essa maioria, por sua vez, pauta o trabalho das Casas, tendo preferência na escolha de presidentes e relatores nas comissões, além das instituições que pautam os trabalhos nos plenários.

\footnotetext{
${ }^{19}$ O papel de relatores dentro de Comissões do Congresso Nacional brasileiro foi bastante explorado por estudos sobre a Assembléia Nacional Constituinte de 1987/1988. Ver, entre outros: Freitas, Moura e Medeiros (2009); Gomes (2006); Martinez-Lara (1996); Pillati (2008); Souza (2003b); Souza (2001).
} 
Contra essa interpretação dos dados, argumento que, se este fosse o caso, não deveríamos encontrar nenhuma alteração às PECs patrocinadas pelo Executivo. De fato, não deveríamos encontrar nenhuma diferença entre as emendas promulgadas e as PECs que as originaram, pois nada que não fosse do interesse do Executivo "andaria" no Congresso Nacional. Qual seria o sentido de o governo arcar com os custos envolvidos no gasto com o tempo de deliberação de sua proposta pelo Congresso Nacional, oferecendo atrasos à implementação de sua política, além dos importantes palanques críticos para a oposição que acompanham cada votação e cada alteração, seja em comissão, seja nos plenários?

Em contrapartida, encontrar alterações às PECs dentro do processo legislativo é indício de que o Congresso Nacional constitui fórum político relevante para decisões que precisam de sua anuência explícita, e que os parlamentares teriam um impacto direto sobre o emendamento da Constituição brasileira de 1988. No mínimo, tais dados, se encontrados, demonstrariam que a coordenação entre governo e base aliada é algo que requer ajustes durante a deliberação parlamentar, e que esses ajustes levam ao afastamento relativo entre o resultado final das emendas promulgadas e as preferências primeiras do governo, evidenciado nas PECs oferecidas. Ou seja, que existem diferenças entre as preferências do governo e o núcleo de preferências de sua base parlamentar, e que essas preferências são publicamente ajustadas também no debate que ocorre no Congresso Nacional, e não somente em bastidores de lideranças parlamentares, ou dentro de salões ministeriais obscuros, sob a batuta do Executivo.

O segundo problema de interpretação dos dados que quero enfrentar é acerca de sua generalidade. Como minha unidade analítica são dispositivos de PECs, e não alterações em instituições ou políticas propriamente ditas, evito uma série de problemas teórico-metodológicos relativos à qualificação de mudanças ou continuidades, porém, ao mesmo tempo, a maior força ilustrativa desse método quantitativo também constitui sua maior fraqueza. Posso oferecer uma rápida visão completa sobre todo o processo pelos quais todas as emendas à Constituição de 1988 passaram, sem precisar gastar inúmeras páginas com histórias sobre cada debate e discussões teóricas sobre o significado de cada votação realizada pelo Legislativo para as políticas que de fato estão por trás das emendas. A divisão em dispositivos também me permite ignorar problemas de nível de ênfase a serem dados ao descrever mudanças em instituições e políticas específicas, pois toda mudança em qualquer dispositivo é considerada igualmente 
relevante, aumentando a comparabilidade para efeitos de avaliar o impacto geral do processo legislativo brasileiro sobre o emendamento da Constituição de 1988.

Essa metodologia, contudo, não deixa de oferecer limitações sobre o fenômeno da mudança e continuidade dessas instituições e políticas tratadas no nível constitucional, justamente porque ignora variações entre elas. Com certeza, a análise a seguir pode se tornar mais refinada com a introdução de elementos qualitativos, e isto, de certa maneira, será feito a seguir, ao introduzirmos a distinção qualitativa entre policy e polity, utilizada pela Metodologia de Análise Constitucional (MAC), dentro do problema específico da relação entre agenda de governo e emendamento constitucional. Outras distinções qualitativas, seguindo problemas analíticos específicos, também podem ser profícuas. Por enquanto, porém, desejo salientar as vantagens de ter uma perspectiva global sobre a relevância do Legislativo (e de cada uma de suas fases deliberativas) sobre o emendamento da Constituição de 1988.

Qual é o universo quantitativo com o qual estamos lidando? Contabilizando em dispositivos os textos de todas as PECs finalmente promulgadas, e de todos os substitutivos aprovados nas fases que deliberaram sobre essas PECs, chega-se ao total de 5175 dispositivos. Desse universo, separei apenas os dispositivos originalmente introduzidos em cada fase e suas alterações posteriores. A análise final, portanto, será sobre (i) os dispositivos originariamente introduzidos nas fases deliberativas (PECs ou etapas deliberativas dentro do Congresso Nacional); (ii) aqueles dispositivos introduzidos, porém eventualmente excluídos; e (iii) eventuais modificações feitas a dispositivos que foram finalmente aprovados. Isto me dá um total de $\mathbf{1 7 7 2}$ dispositivos introduzidos durante o processo legislativo (seja através da PEC original, seja através dos substitutivos), dentre os quais $\mathbf{1 0 3 9}$ foram promulgados (alterados ou não) e $\mathbf{7 3 3}$ não foram aprovados sob nenhuma forma.

O valor de 1039 dispositivos aprovados até 2010 dista do valor encontrado por Arantes e Couto (2011, no prelo) de 1042 dispositivos por algumas questões metodológicas. A primeira é a de que a base de dados de Arantes e Couto vai até a emenda constitucional $n^{\circ} 66$, e a minha vai até a emenda $n^{\circ} 67$. A segunda razão é o fato de Arantes e Couto incluírem também as seis emendas constitucionais de revisão, enquanto eu as excluí da minha análise. Optei por não agregar as emendas constitucionais de revisão, em razão do seu procedimento diferenciado de aprovação, envolvendo maioria simples do Congresso Nacional em sessão unicameral, e cuja utilização foi restringida à cinco anos após a promulgação do texto original (art. $3^{\circ}$ dos 
ADCTs). Uma terceira razão que explica a diferença em número absoluto de dispositivos de emenda aprovados nos dois bancos é o fato de Arantes e Couto contabilizarem cada dispositivo revogador de texto constitucional, contido em uma emenda, como um único dispositivo, avaliando seu impacto em termos de número de revogações efetivamente realizadas em separado. No meu banco de dados, eu contabilizei cada revogação de dispositivo constitucional como um dispositivo independente, o que leva a um aumento no número total de dispositivos em relação à Arantes e Couto. Por fim, eu apliquei a MAC sobre os dispositivos de emendas constitucionais ao longo do processo legislativo, enquanto Arantes e Couto elaboraram seu banco a partir das emendas efetivamente aprovadas. No meu banco, uma vez identificada a aparição de um novo dispositivo nas PECs ao longo do processo legislativo, eu procedia então a avaliar sua evolução, até eventual promulgação, ou exclusão do dispositivo na PEC. Ocorre que em alguns casos, um dispositivo originalmente introduzido no processo legislativo poderia ser desmembrado em dois dispositivos na emenda finalmente aprovada ou, ao contrário, dois ou mais dispositivos introduzidos ao longo do processo legislativo poderiam juntar-se em um único dispositivo de emenda aprovada. Em razão dessas junções e separações de dispositivos ao longo do processo legislativo, e do fato do meu banco ter sido elaborado a partir da introdução dos dispositivos, e não da sua redação final, isso também pode acarretar alguma discrepância no número absoluto de dispositivos aprovados, em relação ao banco de Arantes e Couto. Não foi possível avaliar exatamente o número de junções e separações ao longo do processo legislativo, mas suas ocorrências são bastante raras, na medida em que a divisão textual da legislação brasileira em alíneas, incisos, artigos e parágrafos é bastante precisa, e em geral bem sucedida em manter contínua a redação de matéria legislativa ao longo do processo legislativo.

Não discriminei na minha análise as alterações feitas em uma segunda ou terceira passagem de uma PEC por uma mesma Casa Legislativa (nunca houve mais de três). Isso porque tal evento ocorreu no caso de quatro emendas constitucionais (emendas 53, 47, 32 e 20), porém com resultados negligentes em termos de dispositivos, introduzindo apenas sete novos dispositivos, dando redação final a vinte e excluindo cinco outros. As emendas que foram aprovadas, portanto, dificilmente ficaram "pulando" entre uma casa e outra, o que indica um alto nível de coordenação entre as duas casas legislativas. O que pode ocorrer com maior intensidade é: quando não há consenso entre as duas casas sobre o conteúdo de uma PEC, ela fica parada, ou então é 
promulgado apenas o texto consensual, como foi o caso da emenda 42 (reforma tributária do governo Lula), transformando o restante em uma nova PEC a ser reintroduzida no processo legislativo. No caso da emenda 42, a parte retirada da emenda aprovada, e posteriormente excluída durante a deliberação da PEC/câmara 228/2004 (emenda constitucional $n^{\circ} 44$ ), dizia respeito à unificação do ICMS. Como medida metodológica, não codifiquei modificações feitas por essas passagens adicionais por uma mesma instância. Vejamos agora os totais:

\section{Tabela 1}

Emendamento Constitucional: dispositivos introduzidos e aprovados, por origem dos proponentes

\begin{tabular}{|c|c|c|c|c|c|}
\hline $\begin{array}{l}\text { PROPONENTES } \\
\text { DISPOSITIVOS }\end{array}$ & EXECUTIVO & $\begin{array}{c}\text { CÂMARA DOS } \\
\text { DEPUTADOS } \\
1 / 3\end{array}$ & $\begin{array}{c}\text { SENADO } \\
\text { FEDERAL } \\
1 / 3\end{array}$ & \begin{tabular}{|c|} 
MAIORIA \\
DAS \\
ASSEMBLÉIAS \\
ESTADUAIS \\
\end{tabular} & Tota \\
\hline $\begin{array}{l}\text { Dispositivos } \\
\text { originais PECs }\end{array}$ & 288 & 152 & 171 & 0 & 611 \\
\hline $\begin{array}{l}\text { Dispositivos } \\
\text { introduzidos } \\
\text { no processo legislativo }\end{array}$ & $(-)$ & 880 & 281 & $(-)$ & 1161 \\
\hline $\begin{array}{l}\text { Dispositivos finalmente } \\
\text { aprovados }\end{array}$ & 56 & 708 & 275 & 0 & 1039 \\
\hline
\end{tabular}

Os resultados sobre a introdução de dispositivos durante o processo legislativo começam a nos descortinar algumas primeiras impressões, começando pelo fato de que as emendas aprovadas são cerca de 1,7 vezes maiores do que as PECs originalmente propostas, o que é evidência de que a interação entre as regras de emendamento e o sistema político-partidário leva a um maior emendamento constitucional, no sentido de que as emendas efetivamente aprovadas tendem a crescer sensivelmente, e não a diminuir ou se manter, quando de sua passagem pelo Congresso Nacional. Esse dado tem repercussões importantes para as teorias de emendamento constitucional, que trataremos no próximo capítulo.

Outro dado importante é que nenhuma emenda constitucional foi aprovada até hoje através do mecanismo contido no inciso III do art. 60 da C.F. Não existe emenda aprovada que tenha sido de iniciativa dos Estados federados. Se existe alguma matéria constitucional de interesse dos Estados sendo tratada, aparentemente é mais fácil fazê-lo 
movimentando as bases de parlamentares dentro do Congresso Nacional, do que negociar a proposição de uma PEC a partir das Assembléias Legislativas nos Estados.

Outro fato relevante é o de que o processo legislativo introduz uma grande quantidade de dispositivos para serem deliberados (1161), quase o dobro daquilo que foi proposto nas PECs iniciais. Muitos desses dispositivos são excluídos, juntamente com muitos dos dispositivos oriundos das PECs originais. O saldo final daquilo que é aprovado, contudo, é altamente favorável ao Poder Legislativo, em detrimento do Poder Executivo, e é especialmente favorável à Câmara dos Deputados, aonde o texto das emendas constitucionais finalmente aprovadas é, em grande parte, definido. O executivo foi diretamente responsável pela introdução de apenas 288 dispositivos (16\% do total introduzido) para serem deliberados pelo Congresso Nacional, e viu apenas 56 desses chegarem incólumes ao texto das emendas aprovadas. Senadores e Deputados, apesar de responsáveis, respectivamente, por apenas 171 e 152 dispositivos propostos via PECs, interferem no conteúdo das propostas colocadas para deliberação no Congresso Nacional através de acachapantes 281 e 880 dispositivos, respectivamente. No total, o Congresso Nacional é responsável por 95\% dos dispositivos das emendas aprovadas, restando 5\% (56) das emendas originados das propostas do Poder Executivo. Esses números indicam fortemente no sentido do funcionamento da hipótese 2 , muito mais do que dá hipótese 1 . Ou seja, é na negociação feita dentro do Poder Legislativo que reside o crescimento constitucional brasileiro, e não em um governo que busca constitucionalizar políticas e instituições para além de seu mandato.

É importante ter em mente que o "presidencialismo de coalizão" dificulta separar, na análise, aquilo que é fruto de iniciativa e interesse estrito dos parlamentares, daquilo que é fruto do patrocínio do governo. Ou melhor, separar definitivamente quais dispositivos de PECs têm por entrepreneur o Poder Executivo federal, daqueles cujos entrepreneurs são atores congressuais, na medida em que o Poder Executivo pode escolher introduzir dispositivos no processo de aprovação de uma PEC através de atores parlamentares fiéis ao governo, após a introdução da PEC inicial. A melhor proxy para definirmos isso é o caput do art. 60 da Constituição Federal, identificando a origem da PEC. Esse problema, contudo, não impede de perceber padrões de interação entre os poderes no emendamento da Constituição. $\mathrm{O}$ fato de que as emendas efetivamente aprovadas foram bastante alteradas durante o processo legislativo (ver tabela 2 a seguir) e, mais ainda, que o "carimbo" do Poder Executivo pode ser encontrado apenas em 5\% daquilo que foi aprovado como texto constitucional desde 1988, permite concluir que o 
fórum de negociação política sobre o texto constitucional de fato se encontra no Poder Legislativo, e não no Executivo. Isso é indicativo de uma dinâmica de negociação parlamentar contribuindo para o emendamento constitucional, e não de um Executivo que mobiliza sua base em seu favor, centralizando em si, antes mesmo do oferecimento de uma PEC bem sucedida, a composição de interesses que irá proporcionar adiante uma votação congressual vitoriosa. Como na guerra, a capacidade de escolher o território familiar de batalha é indicativo da força do oponente.

\section{Tabela 2}

Taxa de alteração das fases do processo de emendamento constitucional.

\begin{tabular}{|l|r|}
\hline FASE DO PROCESSO LEGISLATIVO & TAXA DE ALTERAÇÃO (\%) \\
\hline CCJ da Câmara dos Deputados & $3,5 \%$ \\
\hline Comissões Especiais na Câmara & $132,0 \%$ \\
\hline 1a Votação Plenário da Câmara & $39,5 \%$ \\
\hline 2a Votação Plenário da Câmara & $3,0 \%$ \\
\hline CCJ do Senado & $36,7 \%$ \\
\hline 1a Votação Plenário do Senado & $20,0 \%$ \\
\hline 2a Votação Plenário do Senado & $9,0 \%$ \\
\hline
\end{tabular}

Taxa de alteração é um indicador que ilustra o quanto determinada etapa do processo de emendamento constitucional constituiu-se como uma oportunidade na qual os atores efetivamente aproveitaram para alterar o texto de uma PEC. Ele é calculado pela seguinte fórmula: (Número de dispositivos modificados + número de dispositivos excluídos + número de dispositivos incluídos) / número de dispositivos que chegaram à fase deliberativa ${ }^{20}$.

$\mathrm{Na}$ tabela 2, é possível separar as fases deliberativas do processo de emendamento constitucional em três grupos. No primeiro estão as etapas que praticamente não foram utilizadas pelos parlamentares para realizar alterações nas PECs: CCJ Câmara, $2^{\mathrm{a}}$ votação em plenário na Câmara e $2^{\mathrm{a}}$ votação no plenário do Senado. Apesar da segunda votação em plenário no Senado ter um valor de taxa de alteração três vezes maior do que os da CCJ da Câmara e da segunda votação no plenário da Câmara, esse valor ainda é três vezes menor do que aquele encontrado no segundo grupo ( $1^{\mathrm{a}}$ votação no plenário da Câmara, CCJ Senado e $1^{\mathrm{a}}$ votação no plenário do Senado). Além disso, os 9\% de taxa de alteração em segunda rodada de votações no plenário do Senado são fruto de a um alto número de dispositivos excluídos nessa etapa

\footnotetext{
${ }^{20}$ Número de dispositivos que chegaram à fase deliberativa é igual ao número de dispositivos modificados + número de dispositivos excluídos + número de dispositivos não-modificados.
} 
do processo legislativo, e esse alto valor de exclusão pode ser creditado quase que integralmente à emenda 42, que teve 102 dispositivos excluídos de sua redação final durante a segunda rodada de votações em plenário no Senado. No segundo grupo, com uma taxa de alteração intermediário, estão as primeiras rodadas de votações na Câmara e no Senado, além da CCJ do Senado. Essas etapas tiveram uma taxa de alteração da ordem de $30 \%$ sobre as PECs sobre as quais deliberaram. Por fim, isoladas no grupo superior, estão as comissões especiais, formadas na Câmara dos Deputados, que tiveram uma taxa de alteração positiva de $132 \%$, ou seja, constituíram, de longe, a melhor oportunidade regimental para fazer alterações nas PECs. Outro fato relevante é o de que as votações em plenário, tanto na Câmara dos Deputados, quanto no Senado Federal, tiveram um papel de "aparar as arestas" daquilo que vem das comissões, pois possuem um resultado negativo da subtração entre dispositivos introduzidos e excluídos.

Mas aonde, afinal de contas, se decide sobre o conteúdo final de uma emenda? Em qual fase se define o conteúdo de uma emenda constitucional?

Tabela 3

Definição do texto da emenda constitucional por fase do processo legislativo.

\begin{tabular}{|c|c|c|}
\hline FASE DE ORIGEM & $\begin{array}{c}\text { NÚMERO DE DISPOSITIVOS } \\
\text { PRESENTES NA REDAÇÃO FINAL }\end{array}$ & $\%$ \\
\hline PEC original & 116 & $11 \%$ \\
\hline PEC original do Executivo & 56 & $5 \%$ \\
\hline $\begin{array}{l}\text { PEC original da } \\
\text { Câmara dos Deputados }\end{array}$ & 13 & $1,20 \%$ \\
\hline CCJ Câmara & 1 & $0,10 \%$ \\
\hline $\begin{array}{l}\text { Comissões } \\
\text { Especiais na Câmara }\end{array}$ & 462 & $44 \%$ \\
\hline $\begin{array}{l}\text { 1a Votação } \\
\text { Plenário da Câmara }\end{array}$ & 226 & $22 \%$ \\
\hline $\begin{array}{l}\text { 2a Votação } \\
\text { Plenário da Câmara }\end{array}$ & 6 & $0,60 \%$ \\
\hline $\begin{array}{l}\text { Total Câmara } \\
\text { dos Deputados }\end{array}$ & 708 & $68 \%$ \\
\hline PEC original do Senado Federal & 47 & $4,50 \%$ \\
\hline CCJ Senado & 152 & $15 \%$ \\
\hline $\begin{array}{l}\text { 1a Votação } \\
\text { Plenário do Senado }\end{array}$ & 75 & $7 \%$ \\
\hline $\begin{array}{l}\text { 2a Votação } \\
\text { Plenário do Senado }\end{array}$ & 1 & $0,10 \%$ \\
\hline Total Senado & 275 & $26 \%$ \\
\hline Total Geral & 1039 & $100 \%$ \\
\hline
\end{tabular}


Novamente, a Câmara dos Deputados como um todo e as Comissões Especiais em particular foram os momentos mais importantes no processo legislativo para a definição dos textos das emendas constitucionais, e isso pode ser visualizado mais claramente pela fase do processo legislativo na qual os dispositivos ganharam redação final. Apenas $11 \%$ do texto das PECs se mantém até a aprovação da emenda, desses 11\%, 6\% são oriundos de PECs apresentadas por parlamentares (Senadores e Deputados Federais) e, como vimos, 5\% advém de PECs do Executivo.

Esses números são forte evidência de que o Congresso Nacional de fato é o fórum político onde se define o texto de uma emenda constitucional, e que a Câmara dos Deputados teve um impacto geral mais relevante do que o Senado Federal no emendamento da Constituição.

Dentro da Câmara dos Deputados, as comissões especiais não apenas são responsáveis por introduzir diversas inovações nas PECs, mas também é onde se excluem muitos dispositivos introduzidos em outras fases, constituindo um momento institucional de deliberação sobre uma PEC com alta taxa de alteração sobre o texto das emendas constitucionais. Também é nas comissões especiais onde se definiu quase metade (44\%) do texto das emendas aprovadas entre 1988 e 2010, sendo que o segundo lugar em definição de texto de emenda constitucional conseguiu estabelecer apenas metade daquilo que as comissões especiais fizeram (22\%). É possível argumentar que, em razão das comissões especiais serem formadas ad hoc para avaliar cada emenda, a capacidade da maioria política influenciar nas deliberações dessas comissões é ainda maior do que nas duas CCJs, ou mesmo nas decisões tomadas em plenário, pois é possível compor essas comissões e sua relatoria de maneira ainda mais afinada com a maioria do momento. Ao mesmo tempo, é possível aproveitar-se do quórum reduzido das comissões especiais (em relação ao plenário) para reduzir os custos da barganha. Talvez por isso mesmo essas comissões especiais tenham maior sucesso em avançarem suas decisões ao longo do processo decisório. Outro dado interessante é que o chamado $2^{\circ}$ turno pelo qual necessariamente uma proposta de emenda constitucional precisa passar possui pouca relevância para o resultado final da emenda, salvo no caso da emenda 42 (reforma tributária), que teve 102 dispositivos excluídos em segunda rodada de votação no plenário do Senado. 
Como visto anteriormente, de modo geral, as PECs cresceram ao longo do processo legislativo. Se aprovadas as emendas constitucionais com o mesmo texto inicialmente proposto, a Constituição brasileira de 1988 teria sido alterada em 611 dispositivos, um valor que ainda assim poderia ser considerado alto (ver Arantes e Couto 2010), porém cerca de $70 \%$ menor do que os 1039 dispositivos que de fato foram promulgados. Sabe-se que essas alterações são, em sua grande maioria, aditivas e modificativas de dispositivos existentes. São raras as exclusões feitas aos dispositivos da Constituição Federal original (Couto e Arantes 2006). Na minha contabilização da redação final das emendas constitucionais, encontrei apenas 61 dispositivos excluídos da Constituição original ${ }^{21}$. Nas PECs originais, esse total é quase o mesmo: 60 dispositivos (porém apenas 25 desses dispositivos excludentes são os mesmo presentes no texto das emendas). Esses valores de dispositivos excludentes, além de relativamente pequenos, mostram que o processo legislativo impacta na Constituição de modo bastante desigual, aumentando o texto das PECs originais em cerca de 60\%, porém não há aumento algum sobre os dispositivos excludentes.

Mas o principal argumento de Arantes e Couto é o de que o texto constitucional é mais alterado onde políticas públicas foram constitucionalizadas, com o curioso resultado de trazer ainda mais constitucionalização de políticas públicas. Mas como o processo legislativo impacta sobre esse mecanismo?

\subsection{O impacto do processo legislativo nas políticas públicas constitucionalizadas}

Outra pergunta importante que pautou essa pesquisa foi identificar o quanto cada fase do processo legislativo contribuiu para o aumento de dispositivos veiculadores de políticas públicas (policy) no âmbito constitucional. Sabe-se que a Constituição brasileira de 1988 foi pródiga ao trazer para o nível constitucional diversos temas tipicamente relegados a níveis subconstitucionais, com impactos para a agenda política (Couto 1997, Arantes e Couto 2006, Melo 2007, Souza 2008). Sabe-se que essa constitucionalização de políticas públicas obriga os diferentes governos a emendarem a Constituição para implementarem as suas agendas. Por fim, sabe-se também que esse contínuo emendamento tem trazido ainda mais dispositivos veiculadores de políticas públicas e maior detalhamento ao texto da Constituição de 1988 (Arantes e Couto 2008

\footnotetext{
${ }^{21}$ Nota metodológica: importante salientar que um único dispositivo revogador contido em uma emenda pode ter um impacto sobre vários dispositivos. Levei isso em conta na elaboração da base de dados, contabilizando não apenas o único dispositivo revogador, mas todos os dispositivos que foram efetivamente revogados da Constituição pelas eventuais emendas.
} 
e 2009). Contudo, não se sabe ainda em qual momento do processo deliberativo ocorre a introdução de nova policy na Constituição.

Isso é importante para entender o mecanismo que está levando a uma maior constitucionalização de políticas públicas. A explicação de Arantes e Couto para o constante emendamento da Constituição está relacionada ao conteúdo promulgado em 1988, que continha em seu bojo um detalhamento excessivo. Isso explica porque, no Brasil, é necessário governar no marco constitucional, alterando-se constantemente dispositivos já existentes na Constituição. Contudo, novos dispositivos de policy vêm sendo acrescentados ao texto constitucional, aumentando ainda mais os custos futuros da governabilidade e criando novas distorções na regra da maioria em temas específicos.

\section{Tabela 4}

Adições, revogações e modificações de polity e policy nas emendas à Constituição brasileira de 1988.

\begin{tabular}{|l|r|r|}
\hline TIPO & POLITY & POLICY \\
\hline ADITIVOS & 211 & 509 \\
\hline REVOGADORES & 13 & 48 \\
\hline SALDO & 198 & 461 \\
\hline MODIFICATIVOS & 111 & 147 \\
\hline
\end{tabular}

Como é possível visualizar na tabela 4, a Carta brasileira cresceu de 1988 a 2010. As 67 emendas constitucionais feitas até hoje produziram um saldo positivo de 461 dispositivos novos de policy e 198 de polity. Tendo em vista que o texto original possuía 1627 dispositivos (Arantes e Couto 2006), esses valores nos dão um crescimento atual de $40 \%$ do texto constitucional, sendo $70 \%$ desse crescimento apenas em policy.

Como explicar esse crescimento? Um governo que encontrasse a detalhada Carta de 1988, a princípio, teria duas opções, se desejasse implementar as políticas pelas quais foi eleito: 1) alterar os dispositivos constitucionais existentes; ou 2) excluir da Constituição os dispositivos que carregassem políticas contrárias às quais desejasse implementar, abrindo caminho para fazê-lo via legislação ordinária. Acrescentar maior detalhamento ao texto constitucional parece um tanto contraintuitivo, mesmo que esse detalhamento, junto com algumas alterações, permitisse mudanças nas políticas existentes. 
Duas explicações podem ser oferecidas para esse resultado. A primeira é a de que o governo da ocasião desejava que suas políticas fossem praticadas mesmo depois que houvesse alternância no poder. Nesse sentido, acrescentar novos dispositivos na Constituição dificultaria que outros governos viessem desfazer aquilo que havia sido atingido pelo governo da ocasião. Ou seja, dada a oportunidade, maiorias presentes governarão sobre maiorias futuras, através da Constituição.

A segunda explicação é um pouco mais complexa e tem a ver com os custos de governar em coalizão. Se observarmos, por exemplo, a emenda constitucional $n^{\circ} 20$, é possível perceber que ao invés de excluir diversos dispositivos constitucionais e relegálos à legislação ordinária, a emenda acrescentou muitos outros dispositivos à Constituição. Como um dos objetivos gerais da reforma era aumentar a capacidade do Estado gerir seu pessoal, criando assim incentivos e desincentivos que aumentassem a eficiência dos funcionários públicos, a atitude mais racional teria sido a de excluir parte do texto constitucional que tratava do funcionalismo público e fazer a reforma via legislação ordinária. De fato, se observarmos o texto inicial da PEC 33 de 1995, que deu origem à emenda 20 , diversos temas candentes que antes estavam especificados no texto constitucional são deixados para a legislação ordinária, tais como o valor do teto da aposentadoria do funcionalismo público, ou mesmo seus requisitos. Tudo isso foi especificado no texto da emenda, ao longo da sua aprovação na Câmara dos Deputados. Isso indica que a intenção inicial até era a de enxugar a regulação constitucional do funcionalismo público, porém o resultado final foi o de crescimento e maior detalhamento da emenda.

As razões disso respondem à hipótese da negociação parlamentar que leva ao maior emendamento constitucional. No caso da emenda 20 (e também de outras emendas), é razoável supor que excluir grandes partes da Constituição poderia encontrar resistência no Poder Judiciário. Além disso, com o andar das reformas do governo FHC, houve toda uma crítica sobre que o governo estava acabando com os direitos, retirando direitos, etc. então uma emenda desconstitucionalizante seria vista com olhos negativos. Por fim, ao longo do processo de aprovação da emenda, diversas objeções foram levantadas no Congresso Nacional, que levaram a um maior detalhamento da PEC, e a um afastamento do resultado final da reforma daquela pretendida pelo Poder Executivo.

Nesse sentido, Arantes e Couto levantam a hipótese de que o processo de aprovação de uma emenda constitucional dentro de uma base partidária heterogênea e fragmentada pode levar a processos de negociação que aumentam o tamanho das 
emendas. Nas palavras dos autores: "As dificuldades de montagem e de sustentação de coalizões majoritárias - especialmente as que precisam atingir maiorias de 3/5 - são bastante conhecidas e não parece descabido inferir que o tamanho considerável a que chegaram certas emendas constitucionais, o número de policies nelas contidas e o impacto de crescimento que tiveram sobre o texto constitucional, decorram dos processos de logrolling inerentes a um cenário de alta fragmentação partidária" (Arantes e Couto 2009, p. 45).

O que essa explicação parece apontar, é que a manutenção da base parlamentar da coalizão passa não apenas pela distribuição de pastas ministeriais e aceitação de emendas ao orçamento, portanto pelo controle sobre parte do orçamento do Executivo, mas também sobre o conteúdo das propostas legislativas. Em um esforço para adequar as propostas do governo às demandas e garantias mútuas exigidas pelos diversos grupos representados nos partidos da base aliada, maior detalhamento das PECs se torna necessário. O crescimento do número de dispositivos entre as PECs inicialmente oferecidas e as emendas finalmente aprovadas no Congresso Nacional certamente parecem corroborar essa visão.

\section{Gráfico 1 Polity e Policy nas PECs e nas Emendas Constitucionais.}
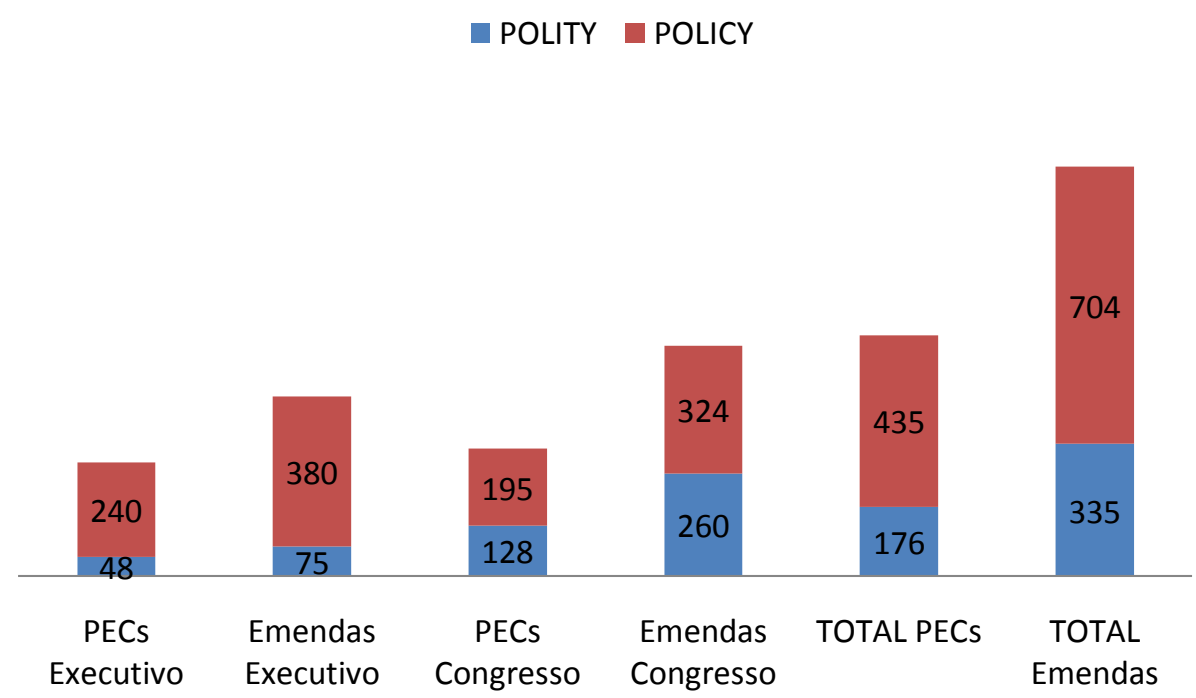

Como é possível notar pelo gráfico, as PECs cresceram ao longo do processo legislativo tanto em policies quanto em polity. Esse crescimento foi o mesmo (ao redor de $60 \%$ ) para policies tanto nas PECs originadas do Poder Executivo quando aquelas originadas no Congresso Nacional, com um crescimento ligeiramente menor de polity nas PECs originadas no Congresso Nacional (50\%), em relação àquelas do Poder 
Executivo (60\%). Isso demonstra que não há praticamente nenhuma variação no crescimento de policy e polity entre as PECs originadas no Poder Executivo, daquelas procedentes de parlamentares. Contudo, é possível perceber que tanto as PECs quanto as emendas originárias do Poder Executivo lidam proporcionalmente muito mais com matéria de políticas públicas do que com polity propriamente dita, em relação às PECs e emendas provenientes do Poder Legislativo.

Esse crescimento, contudo, foi desigual ao longo das fases deliberativas de uma PEC no Congresso Nacional, senão vejamos:

\section{Tabela 5}

Introdução de dispositivos durante o processo de emendamento constitucional polity.

\begin{tabular}{|c|c|c|c|c|c|c|c|c|c|c|}
\hline \multirow[t]{2}{*}{ 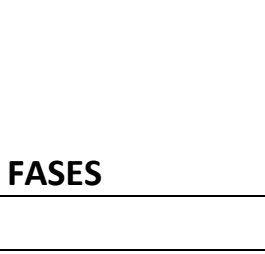 } & \multicolumn{2}{|c|}{ EXECUTIVO } & \multicolumn{2}{|c|}{$\begin{array}{c}\text { CÂMARA } \\
\text { DOS } \\
\text { DEPUTADOS } \\
1 / 3\end{array}$} & \multicolumn{2}{|c|}{$\begin{array}{c}\text { SENADO } \\
\text { FEDERAL 1/3 }\end{array}$} & \multicolumn{2}{|c|}{$\begin{array}{c}\text { MAIORIA } \\
\text { DAS } \\
\text { ASSEMBLÉIAS } \\
\text { ESTADUAIS }\end{array}$} & \multicolumn{2}{|c|}{ TOTAL } \\
\hline & POLITY & POLICY & POLITY & POLICY & POLITY & POLICY & POLITY & POLICY & POLITY & POLICY \\
\hline $\begin{array}{l}\text { Dispositivos } \\
\text { originais PECs }\end{array}$ & 48 & 240 & 75 & 77 & 53 & 118 & 0 & 0 & 176 & 435 \\
\hline $\begin{array}{l}\text { Dispositivos } \\
\text { introduzidos } \\
\text { no processo } \\
\text { legislativo }\end{array}$ & $(-)$ & $(-)$ & 319 & 561 & 59 & 222 & $(-)$ & $(-)$ & 378 & 783 \\
\hline $\begin{array}{l}\text { Dispositivos } \\
\text { finalmente } \\
\text { aprovados }\end{array}$ & 19 & 37 & 158 & 380 & 102 & 177 & 0 & 0 & 279 & 594 \\
\hline
\end{tabular}

A tabela 5 basicamente reproduz as conclusões da tabela 1, diferenciando por polity e policy. Nela, novamente, é possível notar que em todas as PECs há um maior tratamento de policies do que de polity, sendo que essa desproporcionalidade é maior nas PECs originadas no Poder Executivo do que naquelas advindas de parlamentares.

A variação entre as mudanças em polity e policy durante o processo legislativo, vislumbrada nos dois quadros, também enseja a realização de um teste adicional ao modelo de Arantes e Couto. Esse teste visa verificar a viabilidade do modelo dentro do processo legislativo, antes da implementação das emendas, comparando se policy é mais alterada que polity durante a tramitação de uma PEC. 
Como já foi dito, o principal achado proporcionado pela MAC em relação ao emendamento da Constituição brasileira de 1988 foi demonstrar como o detalhamento do texto constitucional convida ao seu emendamento no curto prazo. Isso porque dispositivos constitucionais que refletem políticas públicas são potencialmente mais controversos do que dispositivos da polity constitucional. Esse achado, contudo, diz respeito a dispositivos inseridos na constituição e que de fato estão produzindo efeitos práticos, refletindo policies ditadas por uma constelação de preferências cujo equilíbrio político em favor de sua manutenção é mais baixo do que aquilo que é inteligível ao modelo como a polity constitucional. Apesar da sua concepção partir de um tipo ideal de Constituição - que apenas contenha direitos individuais fundamentais, direitos políticos, regras gerais do funcionamento do Estado e do jogo político e princípios gerais em busca de maior igualdade material - o modelo deduz que o seu funcionamento ideal não se limita a refletir valores idealmente constitucionais, mas tem efeitos muito práticos na própria disputa política e, como consequência, na estabilidade relativa do texto constitucional. Em outras palavras, apesar de ter sido construído a partir de um ideário da filosofia política, tratando daquilo que deveria constar em uma Constituição, particularmente dentro de uma democracia, trata-se de um modelo pragmático, voltado à efetiva disputa política ao redor de políticas públicas que de fato distribuem recursos de poder na sociedade.

O modelo, contudo, supõe um ideal sobre o que deve ser uma Constituição. Esse ideal se alicerça na suposição de que determinadas disposições normativas e instituições políticas, ocasionalmente refletidas em textos constitucionais, são mais consensuais do que outras, ou seja, que atores políticos, e uma sociedade democrática como um todo, tenham como valores determinado tipo de norma constitucional, e se orientam mais frequentemente de acordo com esses valores, em favor da manutenção de dispositivos constitucionais consensuais que os reflitam. Vale à pena uma transcrição de uma passagem de Arantes e Couto (2006, g.n.):

“Justamente por definir os parâmetros da convivência poliárquica, a estrutura constitucional se alicerça sobre um indispensável consenso mínimo dos diversos atores políticos quanto a seus aspectos centrais. Dado se tratar de um acordo institucional básico - um pacto implícito ou explícito entre os atores poliárquicos - os dispositivos por ele estabelecidos têm caráter não controverso, isto é, não dizem respeito àquilo que a competição democrática tem como finalidades (...)" 
A pergunta que quero testar a seguir é: 1) o modelo funciona (no sentido de conseguir prever eventos com uma razoável certeza estatística) porque, em uma sociedade democrática, as pessoas em geral e os atores políticos em particular partilham de um mesmo ideário sobre o que deve ser uma Constituição, e determinam sua ação política de acordo com esses valores, o que acaba tornando constitucionalmente mais estáveis determinadas partes do texto constitucional em detrimento de outras menos consensuais; ou 2) existe outro mecanismo em funcionamento que não os "valores" dos atores políticos conformam seu comportamento e, portanto, a "ação política"? Presumivelmente, esse outro mecanismo está relacionado à distribuição de recursos e poder entre os atores políticos, que emprestam maior estabilidade a determinadas partes do texto constitucional e não a outras. A segunda hipótese nos leva a crer que os atores políticos possuem preferências tão fortes tanto em relação à polity quanto à policy, e que o que o modelo presume ser consensual nada mais é do que uma função política que possui maior equilíbrio de poder do que aquilo presumido como "menos" consensual. Dada a oportunidade, atores políticos irão se movimentar para alterar a polity constitucional tanto quanto a policy no sentido de suas próprias preferências, tão intensas e controversas em relação a uma categoria analítica quanto em relação à outra (ou até mesmo mais controversas em relação a determinada polity, em comparação a uma policy específica). A questão é que essa oportunidade se apresenta mais raramente para a polity do que para a policy, por causa de equilíbrios de poder produzidos de maneira relativamente desigual entre as duas categorias analíticas, em razão de diferenças entre as políticas, regras e instituições que porventura se encontram reproduzidas no texto constitucional.

Analisando as emendas constitucionais, Arantes e Couto já demonstraram que a Constituição muda mais em policy do que em polity. Contudo, esse dado em si pode ser indicativo tanto do mecanismo 1, quanto do 2. Uma pista que nos ajudaria a definir entre 1, ou 2 é avaliar o que muda mais durante a tramitação de uma PEC, se a polity ou se a policy. Isso porque, durante a tramitação, as alterações a serem produzidas pela PEC ainda não surtem efeitos, e são discutidas meramente no plano das expectativas sobre seus efeitos e dos valores envolvidos em cada tema. Ou seja, não está se escolhendo sobre dois status quo que efetivamente estão distribuindo recursos políticos na sociedade, pois isso é impossível, mas entre diversas opções que poderão vir a fazêlo ou, no máximo, entre um status quo e novas opções. 
Como estamos observando a tramitação apenas das PECs que foram efetivamente aprovadas, se houver proporcionalmente mais mudança em policy do que em polity, isso é indicativo de que, de fato, a polity tratada no nível constitucional é mais consensual do que a policy, pois mesmo antes de produzir efeitos, os dispositivos de policy mobilizam proporcionalmente mais os parlamentares a divergirem sobre as opções em pauta, e a aprovarem alternativas nas diversas instâncias deliberativas, do que no caso daqueles dispositivos veiculadores de polity. Se, do contrário, houver proporcionalmente tanta mudança em polity quanto em policy durante o processo legislativo, ou se houver maior alteração em polity do que em policy isso é indicativo de que ambas as categorias analíticas são igualmente controversas na mente dos legisladores, e o modelo não explica a sua variação durante o processo legislativo. De qualquer maneira, vale à pena levar o modelo um passo além, e avaliar se, mesmo antes de produzir efeitos, dispositivos veiculadores de policies conjuram maior controvérsia e mais alterabilidade, antes de serem implementados.

Se a tabela 5 for novamente visualizada, é possível armar algumas simples comparações entre o número de dispositivos que entram para deliberação no processo legislativo, com aquilo que ocorre dentro dele. Se dividirmos o número de dispositivos das PECs originais pelo número de dispositivos aprovados, separando polity e policy, temos as respectivas razões de 0,63 e 0,73. Ou seja, a variação da polity entre as emendas aprovadas e as PECs inicialmente oferecidas foi ligeiramente maior do que a variação de policy. Isso é indicativo de que o processo legislativo aumenta o tamanho da Constituição quase que na mesma proporção tanto em policy quanto em polity. O que ocorre é que a pauta de policy que chega ao Congresso Nacional é cerca de duas vezes e meia a pauta de polity - apesar da Constituição possuir muito mais polity do que policy - em boa medida em razão da pauta oferecida pelo Poder Executivo ser composta majoritariamente de policy, enquanto que a pauta dos parlamentares, apesar de ainda desproporcional em relação ao conteúdo do texto constitucional, é mais equilibrada.

Outra maneira de avaliar o quanto a polity e a policy foi controversa durante o processo legislativo é dividir o número de dispositivos nas PECs iniciais pelo número de novos dispositivos, introduzidos nos diversos substitutivos aprovados durante o processo legislativo. Essa proporção é de 0,46 para polity e de 0,55 para policy, novamente indicando que, ao longo do processo legislativo, houve uma disputa ligeiramente maior ao redor da polity do que da policy, apesar de que, novamente, vale à pena lembrar, em números absolutos, a policy sempre ultrapassa a polity, seja em 
número de dispositivos oferecidos nas PECs, introduzidos ao longo do processo legislativo ou aprovados nas emendas constitucionais.

Um último teste que podemos fazer é criar uma taxa de alteração (ver quadro 2) para o processo legislativo como um todo. Para tanto, é só dividirmos a soma do (número de dispositivos modificados + número de dispositivos excluídos + número de dispositivos incluídos), em cada uma das fases do processo legislativo, pelo número de dispositivos introduzidos para deliberação pelo Congresso Nacional, controlando por polity e policy. O resultado é a seguinte tabela:

\section{Tabela 6}

Taxa de alteração durante o processo legislativo, por polity e policy.

\begin{tabular}{|l|r|}
\hline FASE DO PROCESSO LEGISLATIVO & TAXA DE ALTERAÇÃO (\%) \\
\hline POLITY & $420,0 \%$ \\
\hline POLICY & $380,0 \%$ \\
\hline
\end{tabular}

Na tabela 6, novamente, é possível visualizar mais claramente que houve maior controvérsia ao redor da polity, do que da policy durante o processo legislativo. Porque existe um número elevado de policy na Constituição Brasileira de 1988 (496 dispositivos em 1627), e porque policy, uma vez implementada, tende a suscitar maior revisibilidade do que polity, existe maior reviosionismo constitucional naqueles dispositivos veiculadores de policy, do que naqueles que tratam de polity, sendo o Poder Executivo o grande iniciador das revisões de policy. Porém, uma vez colocado em pauta, até a sua aprovação final, policy e polity são fruto do mesmo nível de controvérsia parlamentar, e de disputas acerca de opções conflitantes, e não é possível deduzir que uma categoria analítica do modelo é, a priori, mais consensual que outra. Elas são mais consensuais ou controversas em razão dos seus efeitos no mundo político. Ou seja, o modelo "funciona" porque as policies refletidas na Constituição estão "funcionando" no mundo, e não porque os legisladores partilham do mesmo ideal de Constituição refletido no modelo.

\subsection{Conclusões.}

Neste capítulo, foi exposto o impacto do processo legislativo no emendamento da Constituição brasileira de 1988. Para construir hipóteses a serem testadas, recorri aos estudos sobre processo legislativo e a interação entre Executivo e Legislativo no Brasil, 
com especial atenção aos trabalhos que procuraram ligar o sistema político brasileiro ao pródigo emendamento da Carta de 1988.

Para instrumentalizar a análise, recorri ao modelo de Arantes e Couto, que divide textos constitucionais em dispositivos, permitindo a quantificação de alterações legislativas ao longo do processo de aprovação de uma PEC. Ao mesmo tempo, o modelo permite avaliar a evolução de dispositivos constitucionais mais diretamente responsáveis pelas contínuas mudanças na Constituição, as policies.

Os resultados nos levaram a concluir diversas coisas. A primeira delas é que, pelo menos no que diz respeito à matéria constitucional, o Congresso Nacional tem um papel fundamental na definição do texto das PECs aprovadas, sendo o Executivo diretamente responsável por apenas 5\% daquilo que consta das emendas aprovadas entre 1988 e 2010. Sabe-se que em diversos temas a Carta brasileira de 1988 desceu a enormes detalhes acerca de políticas públicas específicas, o que regularmente obriga à formação de maiorias qualificadas no Congresso Nacional, aumentando os custos da governabilidade. Esses custos são ainda maiores especificamente no caso de processos de emendamento constitucional, pois muitas das ferramentas de interferência do Executivo no processo legislativo não estão disponíveis no caso de emendas à constituição. Contudo, até então, essa dinâmica não era vista como um empecilho à iniciativa do Executivo, na medida em que se sabe a capacidade de aprovação de matérias de interesse do governo, através da formação de amplas e fiéis coalizões congressuais, e dos poderes de agenda da Presidência da República. Isso fica ainda mais evidenciado se observarmos o elevado número de emendas aprovadas, apesar das dificuldades que apontei acima.

Contudo, poucos estudos haviam conseguido quantificar o impacto dessa interação entre Legislativo e Executivo nas propostas legislativas que são efetivamente aprovadas. O foco nas votações em plenário, na fidelidade de parlamentares às suas lideranças e ao governo, e na distribuição do orçamento federal, descortinou o mecanismo que produz governabilidade no sistema, mas não elucida qual papel (se algum) o Congresso Nacional tem na formulação legislativa efetiva. Análises mais simplistas, em geral veiculadas na imprensa, chegam a acusar o Poder Legislativo de apêndice do Executivo, mero "carimbador" das Medidas Provisórias elaboradas pelo Presidente, lugar no qual sempre se aprova aquilo que chega ao plenário pela mão invisível do governo. Longe disso, os dados apresentados aqui demonstram que o Congresso Nacional é locus de negociação e decisão política efetiva acerca do conteúdo 
das emendas constitucionais. E se emendas constitucionais e a própria constituição estão carregadas de detalhes sobre políticas públicas, às quais nenhum governo se exime de enfrentar, caso pretenda implementar a sua agenda própria, então esse locus de poder se torna ainda mais relevante no peculiar constitucionalismo brasileiro.

Não pretendo criticar o fato de o Poder Legislativo oferecer empecilhos à aprovação legislativa das emendas, e desviar as preferências iniciais do Executivo em direção ao núcleo de preferências das negociações ocorridas no Congresso Nacional. Democracia é barganha, acordo, composição de interesses e respeito às minorias geralmente melhor representadas no Poder Legislativo. Os dados que apresento apenas procuram ilustrar como essa dinâmica de interação entre os poderes afeta o resultado do processo legislativo. A extensão dessa metodologia à matéria subconstitucional certamente nos traria informações valiosas sobre o quanto os poderes constitucionais da Presidência da República (pedido de urgência, veto, iniciativa exclusiva) afetam a produção legislativa, vis-à-vis as emendas constitucionais.

Também demonstrei que as previsões do modelo de Arantes e Couto acerca da maior controvérsia e consequente instabilidade de disposições de policy em relação à polity não se concretizam quando o modelo é aplicado dentro do processo legislativo. Isso porque, apesar do modelo ter sido construído segundo um ideário filosófico político que harmoniza princípios democráticos com o viés antimajoritário embutido na noção de constitucionalismo, o seu funcionamento é dependente do efeito concreto da distribuição de incentivos realizada pelas políticas públicas e instituições constitucionalizadas.

Outra descoberta é o fato das PECs aprovadas terem crescido sensivelmente ao longo do processo legislativo. Ao que tudo indica, é a negociação dentro do Congresso Nacional que define o conteúdo do emendamento da Constituição de 1988. Essa é a Constituição repleta de detalhes sobre políticas de governo, e esse é o mesmo Congresso Nacional no qual, para se formar uma maioria de 3/5 nas duas casas, é necessário reunir um número expressivo de parlamentares de procedências territoriais e partidárias razoavelmente heterogêneas. Essa dinâmica de um Executivo com amplos poderes de agenda, ao lado de uma base congressual fiel, porém heterogênea, tem um sensível impacto no conteúdo e no tamanho daquilo que é aprovado como emenda à Constituição. Longe de reduzir o crescimento da Constituição, a combinação entre maiorias excepcionais (3/5) e heterogeneidade parlamentar aumentou o tamanho das emendas efetivamente aprovadas. 
Esse crescimento constitucional durante o processo legislativo de aprovação de uma emenda, a despeito do quórum qualificado e da fragmentação partidária, nos leva a reconsiderar importantes hipóteses sobre o impacto de regras de emendamento sobre a mudança constitucional, trabalhadas teórica e empiricamente na literatura comparada.

A seguir, iremos retomar as teorias que relacionam rigidez constitucional às taxas de emendamento de constituições, à luz dos achados expostos neste capítulo. Os dados encontrados acerca do impacto do processo legislativo no emendamento da Constituição brasileira de 1988 não apenas nos informam da incompletude dos modelos comparativos existentes, mas apresentam resultados contraintuitivos sobre a relação entre regras de emendamento constitucional e taxas de mudança de Constituições.

Para demonstrar esses problemas, primeiramente irei retomar as teorias que relacionam taxas de emendamento constitucional às regras de emendamento das Constituições, direcionando o argumento teórico-metodológico para a falta de considerações sobre a relação entre as regras de emendamento e a efetiva dificuldade comparativa de formação de maiorias qualificadas, em contextos de heterogeneidade de preferências (presumivelmente partidárias). Em seguida, retomarei os achados expostos neste capítulo, demonstrando que a combinação entre rigidez constitucional e fragmentação partidária podem ter um efeito contraintuitivo às teorias existentes. 


\section{RIGIDEZ CONSTITUCIONAL E EMENDAMENTO CONSTITUCIONAL.}

A literatura comparada sobre emendamento constitucional há algum tempo vem buscando relacionar taxas de emendamento constitucional à noção de rigidez constitucional. Rigidez constitucional é uma medida dos custos impostos por determinada regra de emendamento. A suposição que envolve essa relação é bastante simples e direta: quanto maior a rigidez, mais difícil para os atores se organizarem e aprovarem uma mudança à Constituição. $\mathrm{O}$ aumento na rigidez leva a uma diminuição na mudança constitucional não apenas por constituir maior empecilho à aprovação de uma emenda, mas também porque, ao saber dessa dificuldade, atores com capacidade para emendar a Constituição deixam de oferecer propostas nesse sentido.

A seguir, farei uma crítica à explicação que deduz taxas de emendamento constitucional a partir de rigidez constitucional, oferecendo uma resposta ao fato de nenhuma das tentativas de correlacionar as duas coisas terem atingido uma resposta satisfatória. Para tanto, recorrerei a três críticas distintas: 1) Crítica metodológica à construção do índice de rigidez constitucional no trabalho pioneiro de Donald Lutz, que primeiro traçou a comparação entre diversos casos; 2) Crítica teórica ao estabelecimento de uma correlação direta entre as duas variáveis, sem avaliar a dispersão espacial de preferências dos atores, à luz da teoria dos atores com poderes de veto; e 3) Finalmente, crítica ao mecanismo suposto na relação inibitória da rigidez constitucional na mudança de constituições, à luz dos achados empíricos expostos no primeiro capítulo.

\subsection{Problemas Metodológicos}

No seu estudo empírico sobre mudança constitucional através de emendamento Lutz (1994) se preocupou em elaborar uma teoria geral de emendamento constitucional. Como variáveis independentes, Lutz considerou o tamanho das constituições (medidas em palavras) e também produziu um índice de rigidez constitucional para explicar a taxa de emendamento das constituições. Para elaborar seu índice, ele relaciona procedimentos para emendar a constituição às taxas de emendamento das constituições dos estados norte-americanos, e extrapola seus achados para países do mundo. Segundo o autor, os procedimentos que remetem o emendamento a consulta popular como o referendo ou a necessidade de que um novo legislativo eleito também aprove a emenda (eleição durante o processo de emendamento) aumentam significativamente a dificuldade de emendar uma Constituição (Lutz 1994, p. 363). 
O estudo de Lutz se tornou referência entre os pesquisadores do tema, pois foi pioneiro em tratar o emendamento constitucional como uma variável dependente. Contudo, sua pesquisa apresenta uma série de problemas metodológicos. Lorenz (2005 p. 351), ao checar os dados de Lutz para Alemanha, França, Irlanda e Nova Zelândia encontra erro nas taxas de emendamento de todos esses países e eu mesmo encontrei erro para a taxa de emendamento da Índia (Lutz afirma ser 7.29, porém meus cálculos apontam $1.71^{22}$ ). Peterlevitz (2010) também encontra taxa de emendamento diversa da de Lutz para a Colômbia no mesmo período analisado e, ao comparar a idade das constituições apontada por Lutz (em 1992) com os dados de Elkins, Ginsburg e Melton, descobre incongruências em 9 dos 32 países.

No Brasil, Melo (2007, p. 243) utiliza os dados de Lutz, concluindo que "a escolha constitucional implica um trade off entre extensão e dificuldade de emendamento", calculando extensão também como o número de palavras. A crítica aos autores que consideram positivamente o número de palavras na taxa de emendamento é a de que não necessariamente uma Constituição com muitas palavras será uma Carta com muitas disposições normativas (ver também apêndice metodológico). É preciso resolver o problema das diferentes línguas, que implicam unidades de idéias distintas em relação às palavras, antes de comparar diferentes textos, e mais do que isso, uma Carta grande pode simplesmente ser fruto de maior retórica constituinte ou da cultura jurídica local, cuja aplicabilidade prática não está necessariamente ligada ao número de palavras utilizadas para descrever um comando legal. Lorenz (2005, p. 352-353), ao contar linhas ao invés de palavras, soluciona o problema da língua, utilizando textos apenas em inglês, porém não encontra uma relação satisfatória entre os índices de Lutz e as taxas de emendamento, e muito menos entre o número de palavras e o número de linhas de um texto constitucional. Após exaustivos testes, Lorenz (2005, p. 355) conclui: “o modelo de Donald S. Lutz que recorre a apenas duas variáveis independentes, rigidez e o tamanho de constituições, não pode ser verificado para uma amostra de democracias estabelecidas entre o período de 1993-2002".

Todos esses problemas metodológicos tornam o estudo de Lutz pouco confiável, porém o principal problema com o seu índice de rigidez constitucional está relacionado à maneira como ele foi produzido. $\mathrm{O}$ índice de Lutz foi criado estabelecendo-se uma correlação tautológica entre rigidez constitucional e taxa de emendamento da

\footnotetext{
${ }^{22}$ Ver Lutz p. 170. A constituição da Índia foi emendada 74 vezes entre 1949 e 1992, período contemplado pelo autor.
} 
constituição. É possível identificar isso na nota do quadro (tabela 5.5) no qual ele cria o seu índice de rigidez, a partir das constituições estaduais americanas (p. 165).

The Amendment Process

TABL: 5.5. Comparative Effect of Majority Size on Amendment Rate in American State Constitutions

\begin{tabular}{|c|c|c|c|c|c|c|}
\hline & \multicolumn{6}{|c|}{ Required Legislative Majority } \\
\hline & $50 \%+\mathrm{T}$ & $50 \%+$ I twice & $60 \%$ & $67 \%$ & $75 \%$ & $67 \%$ twice \\
\hline $\begin{array}{l}\text { Ratio of difficulty to } \\
\text { simple majority }\end{array}$ & $\begin{array}{l}\mathrm{I} .00 \\
(\mathrm{II})\end{array}$ & $\begin{array}{l}1.04 \\
(6)\end{array}$ & $\begin{array}{l}1.26 \\
(9) \\
\end{array}$ & $\begin{array}{l}1.62 \\
(19)\end{array}$ & $\begin{array}{l}\mathrm{I} .83 \\
(\mathrm{I})\end{array}$ & $\begin{array}{l}3.56 \\
(4) \\
\end{array}$ \\
\hline \multicolumn{7}{|c|}{$\begin{array}{l}\text { Note? In this table, the decline in the amendment rate produced by each type of legislative } \\
\text { maifority has been normed against that of the lcast difficult method. This norming is accom- } \\
\text { plished by taking the simple (bicameral) legislative majority and dividing it by the success rate } \\
\text { of proposals initiated by a two-thirds legislative majority, a three-fourths majority, etc. - always } \\
\text { kecping the other variables constant. For example, the data indicate that in the American states, } \\
\text { when the method of initiation is stiffened to require approval by a simple (bicameral) legislative } \\
\text { approval twice, the amendment rate is reduced from the baseline of } 7 \mathrm{I} \% \text { to a little over } 68 \% \text {. } \\
\text { Dividing } 71 \% \text { by } 68 \% \text { results in an index score of r.0. Likewisc, a requirement for a three-fifths } \\
\text { (bicameral) legislative majority results in a success rate of } 56 \% \text {. Dividing } 7 \mathrm{I} \% \text { by } 56 \% \text { produces } \\
\text { an index score of } \mathrm{r} .26 \text {. A score of } 2.00 \text { therefore indicates a method that is twice as difficult, a } \\
3.00 \text { indicates a method three times as difficult, and so on. Table } 5.3 \text { arrays the empirical results } \\
\text { from lowest to highest level of difficulty rather than according to any theorctical prediction. } \\
\text { The results arc mostly in line with commonsense expectations (although why a second majority } \\
\text { vote has so little effect while a second two-thirds vote has so much is not clear). }\end{array}$} \\
\hline
\end{tabular}

Acima, eu reproduzi a tabela juntamente com a nota para facilitar a visualização do problema com o índice de $\mathrm{Lutz}^{23}$. O título do quadro é importante: "Efeitos

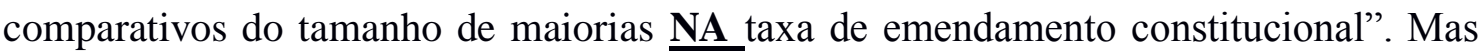
será isso mesmo que está sendo calculado? Uma leitura atenciosa da nota de rodapé mostra o contrário. A adição de dificuldade promovida por um aumento na maioria parlamentar requerida para emendar o texto de uma constituição foi calculada a partir do aumento incremental na taxa de emendamento entre as constituições estaduais americanas. No quadro acima, portanto, não resta claro qual é a variável dependente e

\footnotetext{
${ }^{23}$ Tradução da nota de rodapé de Lutz: “Nesta tabela, o declínio na taxa de emendamento produzido por cada tipo de maioria legislativa foi normalizado em relação ao mais fácil dos métodos de emendamento. Essa normalização é atingida tomando-se uma maioria (bicameral) simples e dividindo-a pela taxa de sucesso de propostas iniciadas por uma maioria legislativa de $2 / 3,3 / 4$, etc. mantendo-se as demais variáveis constantes. Por exemplo, os dados indicam que, nos Estados americanos, quando o método de emendamento é endurecido ao requerer duas votações por maiorias simples em duas Câmaras, a taxa de emendamento é reduzida de uma base de $71 \%$ para uma de $68 \%$. Dividindo-se $71 \%$ por $68 \%$ resulta num índice de 1,04 . Da mesma maneira, o requisito de $3 / 5$ em votação bicameral resulta numa taxa de sucesso de $56 \%$. Dividindo $71 \%$ por $56 \%$ produz um índice de 1,26 . Um índice de 2,0, portanto, indica um método duas vezes mais difícil, e um de 3,0 indica um método 3 vezes mais difícil e assim por diante. A Tabela 5.3 os resultados empíricos do mais baixo ao mais alto ao invés de utilizar qualquer tipo de previsão teórica. Os resultados são, em sua maioria, de acordo com expectativas do senso comum (apesar de que a razão pela qual uma segunda votação em maioria simples tem um efeito tão reduzido, enquanto uma segunda votação em uma maioria de $2 / 3$ possui um efeito tão alto não é clara). Os números em parênteses indicam o número de Estados utilizando determinado método de emendamento."
} 
qual é a variável independente. Um aumento no índice de dificuldade está "causando" uma diminuição na taxa de emendamento, ou uma diminuição na taxa de emendamento está "provocando" um aumento na dificuldade de emendar uma constituição?

O procedimento adequado seria construir um índice de dificuldade de maneira empiricamente independente da taxa de emendamento, e então testá-lo em relação a ela, para verificar a relação entre as duas variáveis. Da maneira como foi feito, o índice foi construído indutivamente a partir da taxa de emendamento constitucional, propondo-se a prevê-la. Ou seja, num primeiro momento o autor afirma que a variação do índice de dificuldade é diretamente proporcional à variação nas taxas de emendamento das constituições e, num segundo momento, ele afirma que o índice de dificuldade prevê a variação na taxa de emendamento. Isso torna a relação entre índice e taxa de emendamento algo redundante logicamente, pois se variação do índice é igual à variação na taxa de emendamento, então, logicamente, a variação na taxa de emendamento será igual à variação no índice de dificuldade. Uma variação no índice, portanto, não me diz se uma Constituição é mais ou menos difícil de ser emendada, mas apenas o número de emendas constitucionais a mais que determinada Constituição de um Estado americano teve em relação à média das Constituições de Estados americanos que adotam o método mais simples de emendamento.

Além desses problemas com os dados, a própria escolha de casos de Lutz não é justificada. Ele junta, por exemplo, constituições autoritárias com constituições democráticas, sem maiores explicações. Para o Brasil, o caso escolhido é a constituição de 1967 em sua vigência entre 1969 e 1988 (ver Lutz 2006, p. 170).

Elkins, Ginsburg e Melton também recorrem a uma estratégia similar para criar um índice que avalie a dificuldade de emendamento de uma constituição. Diferentemente de Lutz, contudo, os autores não se propõem a explicar taxas de emendamento constitucional (número de emendas/ano), mas sim a morte das constituições. Portanto, a relação é estabelecida entre duas variáveis distintas, permitindo comparações.

A produção da variável "rigidez constitucional" ou, como os próprios autores denominam, "facilidade de emendamento", é feita

"modelando a taxa de emendamento e estimando o efeito de cada regra de emendamento, controlando os efeitos de todas as demais variáveis independentes. Dessa maneira, nós regredimos a taxa de emendamento em um conjunto de variáveis de procedimentos de emendamento, assim como em uma variedade de outros fatores no nosso modelo de durabilidade das constituições. 
A unidade de análise nesse modelo é o sistema constitucional, e a variável dependente é binária, capturando se um determinado sistema constitucional foi ou não foi emendado em um dado ano. $\mathrm{O}$ modelo produz estimativas utilizando regressão logística, incluindo todas as variáveis independentes do nosso modelo principal, assim como variáveis que capturam os procedimentos de emendamento (...). Após a produção do modelo estimativo, nós predizemos a probabilidade de emendamento para cada sistema constitucional, constrangendo todas as demais variáveis para as suas médias, com exceção das variáveis que capturam os procedimentos de emendamento" (Elkins, Ginsburg e Melton 2009, p. 101).

A estratégia, portanto, é a mesma utilizada por Lutz: deduz-se a rigidez de cada procedimento de emendamento a partir da sua variação em relação às taxas de emendamento de vários casos. O modelo de Elkins, Ginsburg e Melton, contudo, é multivariado e inclui, além dos procedimentos de emendamento (tal como feito por Lutz), também outras variáveis independentes de seu modelo mais amplo, o qual pretende predizer mudança constitucional. Essas outras variáveis são diversas, e vão desde a ocorrência de guerras, mudanças de regime por via extra-constitucional ou intra-constitucional, ocorrência de crise econômica, perda ou ganho de território, transições democráticas, variedade étnica, idade do Estado, localização geográfica, etc ${ }^{24}$. O modelo também incorpora mais casos do que os 50 tratados por Lutz, além de utilizar sistemas constitucionais nacionais, e não estaduais ${ }^{25}$.

Apesar da estratégica indutiva, as conclusões dos autores de endurance não guardam o mesmo problema presente em Lutz. A única correlação estabelecida com a variável "facilidade de emendamento" é entre ela e a probabilidade da morte de uma constituição. No modelo dos autores, a variável "morte constitucional" é dependente da variável "facilidade de emendamento", a qual nada mais é do que um reflexo do número de emendas constitucionais feitas a cada Constituição inserida na base de dados, controlando-se as demais variáveis. Ou seja, mede-se a correlação entre "facilidade de emendamento" e o evento "morte de um sistema constitucional", e não entre "facilidade de emendamento" e "taxa de emendamento", que na prática são a mesma coisa se o índice for construído dessa maneira. A conclusão a que os autores chegam é a de que uma constituição "fácil" de ser emendada tem maior probabilidade de ser uma constituição longeva. A correlação, contudo, não é muito forte, como demonstrável pela exceção da Constituição dos EUA.

\footnotetext{
${ }^{24}$ Para maiores detalhes, ver p. 225 a 229 de Elkins, Ginsburg e Melton (2009) e também o apêndice metodológico do livro disponível no site (18/08/2010).

${ }^{25}$ Elkins, Ginsburg e Melton (2009) fazem uma importante distinção entre ambas (ver nota 13, p.50).
} 
Outra correlação possível de ser estabelecida pelos autores é entre "facilidade de emendamento" e "abrangência em tópicos" de uma constituição, após cada emenda. Isso porque o índice de abrangência, como vimos, é um indicador do conteúdo das cartas, e foi produzido de maneira independente da noção de rigidez, portanto relacionar as duas coisas seria logicamente contingente. Os próprios autores não testam essa correlação, o que seria uma maneira de indicar o impacto das regras de emendamento no texto da constituição em vigência. Existe apenas um exercício interessante nesse sentido, quando eles relacionam o impacto da própria taxa de emendamento constitucional no texto da constituição sem, contudo, dar um passo anterior e verificar o impacto das regras de emendamento no emendamento constitucional. Esse exercício está entre as páginas 55 e 59 , e trata sobre "A divisão por vezes confusa entre emendamento e substituição". Nesse trecho do livro, os autores discutem a situação na qual uma constituição foi tão emendada que talvez seja possível falar de uma nova carta.

\subsection{Rigidez Constitucional e Atores com Poderes de Veto}

Para além dos problemas teórico-metodológicos envolvidos na relação entre rigidez constitucional e emendamento das constituições, existem ainda problemas mais fundamentais de fundo puramente teórico a serem considerados.

Os modelos que até o momento buscaram identificar a relação entre taxa de emendamento e rigidez constitucional avançaram bastante na busca de uma relação entre as regras de emendamento constitucional podem impedir ou facilitar que uma constituição seja alterada, mas apesar do investimento teórico metodológico, ainda não se produziu uma teoria do emendamento constitucional a partir da noção de rigidez da regra de emendamento ${ }^{26}$. Isso se deve em razão de, curiosamente, não se ter exatamente trabalhado em uma teoria sobre porque constituições são emendadas, mas sim em uma teoria sobre porque constituições não são emendadas.

O problema que deriva disso é similar àquele identificado por Jairo Nicolau, no seu estudo sobre a relação entre o sistema eleitoral e o sistema partidário brasileiro. No trabalho do autor, ele conclui que a explicação produzida a partir do modelo de Duverger, segundo a qual o sistema eleitoral determinava o número de partidos, era insuficiente (1996). A fragmentação do sistema partidário brasileiro não poderia ser

\footnotetext{
${ }^{26}$ Nas suas conclusões, Lorenz (2005, p. 355) aponta esse impasse da literatura: "Será que o efeito próintuitivo da rigidez constitucional tem sido superestimado? Ou devemos buscar explicação na sabedoria deveras comum de que qualquer análise comparativa, a qual necessariamente precisa basear-se em apenas poucas variáveis, necessariamente está aquém de explicar tudo com absoluta perfeição?”
} 
explicada somente pelas regras eleitorais. De acordo com o autor, assim como a rédea serve para segurar o cavalo, mas não consegue fazê-lo correr, sistemas eleitorais restritivos são ótimos para diminuir o número de partidos políticos, porém sistemas eleitorais permissivos são condição necessária, mas não suficiente, para produzir fragmentação partidária. Da mesma maneira, economistas nos lembram que taxas de juros altas são excelentes para reduzir a demanda, ao criar incentivo para o direcionamento de recursos para o sistema financeiro, aumentando o custo do crédito e inibindo consumo e investimento, porém a redução da taxa de juros não é suficiente para produzir demanda por investimento e consumo.

Assim também funciona a rigidez constitucional e o emendamento da constituição. Rigidez constitucional é condição suficiente para restringir o emendamento constitucional, porém é apenas condição necessária para que ele possa ocorrer. É necessário o desenvolvimento de uma teoria da demanda por emendamento constitucional, para poder avançar nesse sentido.

$\mathrm{O}$ que todas as teorias sobre rigidez constitucional possuem em comum é que elas são teorias sobre a estabilidade das constituições e não teorias da mudança constitucional $^{27}$. Constituições menos rígidas são mais emendadas do que constituições mais rígidas, mas não se sabe exatamente de onde vêm as pressões para que as Constituições sejam emendadas em primeiro lugar. A única referência a isso nos trabalhos de Lutz (2006), Elkins, Ginsburg e Melton (2009) é feita em relação a uma noção geral de que o tempo necessariamente obriga a mudança constitucional.

De modo geral, as teorias sobre rigidez constitucional se apóiam naquilo que se encontra de maneira mais organizada no trabalho de Tsebelis sobre "atores com poderes de veto". Nesse sentido, a noção de rigidez constitucional é uma tentativa de quantificar o impacto do aumento no número de atores, votações e arenas decisórias exigidas para alterar um texto constitucional, à diminuição do emendamento de uma constituição. Ou seja, no quanto o aumento de atores com poderes de veto favorece a manutenção do status quo constitucional. Nas palavras de Tsebelis (2009, p. 235) "(a teoria dos atores com poder de veto) prediz que a estabilidade decisória, definida como a impossibilidade de mudança significativa no status quo, é resultado de muitos atores com poder de veto, especialmente se eles têm diferenças ideológicas significativas entre si”. Esse poder de

\footnotetext{
${ }^{27}$ Existe uma relação entre rigidez constitucional e mudança constitucional tanto em Lutz (2006) quanto em Elkins, Ginsburg e Melton (2009): excesso de rigidez constitucional pode levar à morte de uma constituição, seja por desuso, seja por substituição por outra mais flexível. Contudo, essas não são teorizações sobre o emendamento textual da constituição.
} 
veto advém das instituições políticas e das regras relativas ao processo decisório, e é sempre relacional, pois o veto sobrevém a uma decisão anteriormente tomada ou a uma demanda previamente suposta e devidamente modelada. Uma maneira típica de sistematizar o impacto das arenas de veto sobre o resultado de uma determinada política em termos comparativos é supor, coeteris paribus, uma mesma demanda política sendo trazida para o sistema nos diferentes casos. A variação se dá em relação às regras do processo decisório, que produzem arenas onde grupos contrários a determinada demanda podem mobilizar-se para barganharem o seu resultado, ameaçando impedi-lo. A mera possibilidade do veto já é suficiente para que a demanda nem mesmo seja apresentada para votação, ou para que uma proposta seja diluída ao ponto de afastar-se relativamente menos do status $q u o^{28}$.

Dessa maneira, a exigência de que uma proposta de emenda constitucional precise ser aprovada por uma segunda câmara legislativa diminuiria a probabilidade de sua aprovação ao adicionar um outro ator no processo deliberativo com capacidade de impedir a aprovação. O mesmo ocorreria quando houvesse a adição de outras arenas de veto no processo deliberativo, tal qual um Executivo, ou mesmo pela exigência de aprovação em um referendo. A exigência de maiorias qualificadas também cria vetos adicionais no processo deliberativo, ao possibilitar que minorias possam impedir uma aprovação em determinada arena. Todas essas arenas de veto podem ainda ter pesos diferentes em sua capacidade de impedir a aprovação de determinada emenda ao texto da constituição ${ }^{29}$.

Apesar de não levar em conta o peso diferenciado que arenas distintas podem ter em vetar uma emenda, Lorenz (2005, p. 346), ao tentar criar seu próprio índice de rigidez constitucional, é quem melhor expressa essa lógica, assinalando pontuações arbitrárias de acordo com as maiorias exigidas em cada uma das arenas com eleitores diferentes, necessárias para a aprovação da emenda. Contudo, há um aspecto importante da teorização sobre atores com poderes de veto ignorado na literatura sobre rigidez constitucional, e que, ao menos no nível teórico, deve levar a uma superestimação do

\footnotetext{
${ }^{28}$ Immergut (1992) aplica essa mesma lógica para estudar as diferenças nas reformas à saúde produzidas na França, Suiça e Suécia. A autora escolhe esses três países justamente porque eles permitem tomar por iguais as demandas por reformas à saúde, e também os grupos políticos mobilizados em direção contrária, variando as matrizes institucionais que proporcionam maior ou menor poder de veto aos diferentes grupos (Immergut, 1992).

${ }^{29}$ Lutz (2006), por exemplo, argumenta que métodos que remetam o processo de emendamento a consulta popular (através de referendo ou eleição interveniente) diminuem consideravelmente a taxa de emendamento constitucional. Em seus estudos de caso, Immergut também salienta o referendo como arma minoritária bastante eficiente (1992).
} 
impacto das arenas de veto nas taxas de emedamento das constituições. Trata-se daquilo que Tsebelis (2009) denomina "regra da absorção".

Pela regra de absorção, para um ator com poder de veto se constituir como tal, não é suficiente apenas a existência de uma regra que torne determinada arena capaz de sustar as deliberações aprovadas por atores com poderes de veto anteriores. Além disso, é necessário que a preferência desse ator distancie-se daquilo que Tsebelis denomina o "núcleo de unanimidade" dos atores com poderes de veto pré-existentes ${ }^{30}$. Dito de outra maneira: se quem decide, mesmo tendo poder para vetar uma proposta, por alguma razão qualquer sempre concorda com aquilo que foi decidido anteriormente, então essa instância, para todos os efeitos, não funciona como um ator com poder de veto. Ele é absorvido dentro de um outro ator ou dinâmica estrutural maior.

Um exemplo de como essa dinâmica pode inviabilizar uma análise adequada da relação entre regra de emendamento e taxa de emendamento constitucional é o caso mexicano entre 1917 e meados da década de 1990. A Constituição mexicana é a mesma nos dias de hoje, desde 1917, e sua regra de emendamento está disposta no artigo 135, que exige que uma proposta de emenda seja aprovada por 2/3 das duas casas legislativas federais, e também pela maioria das assembleias dos Estados membros da federação mexicana. Trata-se de uma regra relativamente exigente, porém no período em questão, o sistema político mexicano era monopolizado por um único partido, o PRI, o que na prática tornava irrelevante o problema de conseguir maiorias qualificadas nos Poderes Legislativos nacional e estaduais, ou, no mínimo, transferia a questão de atingir consenso e emendar a constituição para fora do parlamento e para dentro do próprio PRI.

Pela regra de absorção, ao observarmos se determinado parlamento se comporta como uma arena de veto, é preciso se perguntar se as preferências majoritárias das unidades que o compõe distam ou não do núcleo de unanimidade do conjunto de atores de veto preexistentes. Mas qual é a unidade relevante na arena parlamentar? A unidade relevante primordial é sempre o indivíduo, mas é preciso descobrir o mecanismo que faz com que as escolhas desse indivíduo se orientem de acordo com um coletivo mais amplo (partido, coalizão ideológica, base eleitoral, governo, oposição, etc.). Fazendo isso, torna-se possível compreender os limites nos quais é plausível desconsiderar esse indivíduo no universo de análise, assumindo que ele é teoricamente absorvido no

\footnotetext{
${ }^{30}$ A postulação de Tsebelis (2009) sobre a regra de absorção é a seguinte (p. 53): "Se um novo ator com poder de veto ' $D$ ' for adicionado ao núcleo de unanimidade de qualquer conjunto de atores com poder de veto preexistentes, 'D' não terá efeito sobre a estabilidade decisória'.
} 
coletivo. Aliás, essa é a disputa ao redor das interpretações sobre o funcionamento do sistema político brasileiro: o parlamentar brasileiro se comporta de maneira errática, formando coalizões ad hoc em diferentes votações, ou ele sempre segue a orientação partidária ou do bloco de partidos ao qual pertence? É possível ainda que a arena institucional com poder de veto precise ser ativada por atores externos a ela, conforme demonstrou Taylor (2008) para o caso do judiciário brasileiro.

Tsebelis (2009) lida com o tema fazendo considerações sobre dispersão ideológica e heterogeneidade dos atores envolvidos no processo decisório, pesquisando casos que tipicamente polarizam direita e esquerda em matéria de legislação trabalhista. Seguindo a teoria sobre atores com poderes de veto, Cox e McCubbins (1999) argumentam que é preciso levar em conta não apenas as arenas decisórias nas quais uma determinada decisão precisa ser aprovada (separation of powers), mas também se essas arenas de fato manifestam interesses distintos entre si (separation of purposes), para compreender melhor o impacto de sistemas políticos sobre escolhas de policy. Para tratar das preferências dos atores, Cox e McCubins supõe preferências políticas a partir de incentivos produzidos particularmente na arena eleitoral. A combinação entre separation of powers com separation of purposes faz com que um sistema tenha dificuldade de produzir decisões, porém ao mesmo tempo faz com que as decisões efetivamente tomadas sejam mais estáveis.

As regras formais de emendamento em si não significam maior ou menor dificuldade de emendar uma constituição, pois é necessário um estudo do espectro partidário e do processo de formação de maiorias para entender quais as reais dificuldades de emendar uma constituição. Uma exigência de $2 / 3$, por exemplo, pode significar muito pouco em um regime de partido hegemônico. É o que se pergunta Lorenz (2005, p. 353): “Talvez a crescente influência de outras variáveis independentes, por exemplo a constelação política, enfraqueça a validade universal do modelo Lutziano de explicação" (g.n.).

As teorias sobre rigidez constitucional que se limitam a contabilizar diferentes regras de emendamento da constituição, sem, contudo, se questionarem sobre as preferências dos atores que efetivamente ocupam essas arenas decisórias, ignoram o quanto estas arenas de fato estão funcionando para limitar o emendamento da constituição, o quanto elas constituem arenas de veto ao emendamento constitucional. 
Contudo, os achados empíricos reproduzidos no capítulo anterior oferecem ainda uma crítica adicional ao estabelecimento de uma correlação simples e direta entre regra de emendamento e mudança constitucional para o caso brasileiro.

\subsection{Regra de Emendamento e Impacto do Sistema Político Brasileiro no Emendamento da Constituição de 1988}

Anteriormente, fiz um esforço para descrever a série de dificuldades e problemas metodológicos e teóricos enfrentados pelos trabalhos que tentaram explicar emendamento constitucional como uma função direta da rigidez das Constituições. A despeito desses problemas, o mecanismo suposto na relação permanece intacto. Se fosse possível solucionar todos os problemas metodológicos, e incorporar a dimensão partidária no conceito de rigidez constitucional, compreendendo assim quais são os custos efetivos para ultrapassar o limiar de aprovação de uma emenda dentro de cada sistema político específico, seria, teoricamente, possível estabelecer uma relação entre rigidez e emendamento, na qual o aumento dessa rigidez levaria a uma diminuição no emendamento de Constituições. A experiência do caso brasileiro, contudo, levanta problemas adicionais que parecem desafiar essa intuição.

Ao contrário do esperado pelos trabalhos comparativos que relacionam rigidez constitucional e emendamento, os dados expostos no capítulo anterior indicaram que houve extenso crescimento e detalhamento das PECs aprovadas durante o processo legislativo. As razões para isso ainda não são totalmente claras, porém os dados sobre o impacto do processo legislativo brasileiro no emendamento da Constituição de 1988 indicam que a negociação com a base heterogênea do governo, dentro do Congresso Nacional, é parte significativa da explicação.

Em seu funcionamento ideal, o conceito de rigidez constitucional seria uma ilustração do quanto diferentes regras de emendamento constitucional poderiam produzir uma variação no número de atores com poderes de veto, e como esses vetos efetivamente reduzem o emendamento constitucional. Um aumento na rigidez significaria uma redução no emendamento. Contudo, do que se sabe atualmente sobre o funcionamento do sistema político brasileiro, aliado ao que se conhece sobre o perfil peculiar da Constituição de 1988, é possível traçar uma narrativa dos dados expostos no capítulo anterior que é contra intuitiva ao funcionamento do mecanismo exposto por trás da noção de rigidez constitucional. 
A narrativa segue em sete etapas: 1) Uma Constituição originalmente detalhada, carregada de políticas públicas, obriga a diferentes governos alterarem o texto original para poderem implementar suas agendas próprias; 2) Para governar no marco constitucional, é preciso com frequência reunir maiorias qualificadas de $3 / 5$, aumentando os custos da governabilidade, tarefa nada fácil em um país onde, em condições normais, o partido do Presidente não dispõe nem mesmo de maioria simples em nenhuma das casas legislativas, precisando negociar com diversos outros partidos diferentes e com interesses distintos do seu; 3) Porém o Poder Executivo é um ator importante no processo legislativo brasileiro, contando com diversos poderes de interferência direta no processo legislativo. Além desses poderes, ele controla importantes fatias do orçamento federal, através das pastas ministeriais e da sua capacidade exclusiva de oferecer peças orçamentárias para a apreciação do legislativo, e de contingenciar verbas ao longo do ano fiscal; 4) Todos esses poderes fazem do Executivo o polo de atração natural de atores legislativos, ao redor do qual se organiza uma coalizão que supera as barreiras institucionais impostas por um presidencialismo multipartidário, constitucional, federativo e bicameral; 5) Contudo, essa coalizão congrega interesses heterogêneos, que precisam ser negociados entre os atores, à despeito da hegemonia do Poder Executivo no processo; 6) Essa composição de interesses heterogêneos leva a extensas negociações, oferecimento de diversas garantias entre as partes, detalhamento de acordos nos quais um lado aceita contemplar os interesses do outro em troca de reciprocidade; 7) Isso resulta em emendas constitucionais mais longas e detalhadas, para levar em consideração todos os interesses e garantias relevantes.

A própria maneira de medir emendamento constitucional pode expressar melhor uma lógica, ou outra. Usualmente, o conceito "taxa de emendamento" é utilizado para medir o quanto um texto constitucional mudou ao longo do tempo. Essa "taxa de emendamento" é criada calculando-se o número de emendas ao longo do tempo (em geral, anos). Medir a mudança constitucional via emendamento dessa maneira salienta os custos fixos envolvidos no processo, e não precisamente o quanto uma Constituição mudou, pois enquanto algumas emendas são muito pequenas (incluem por vezes apenas palavras em um artigo), outras são tão grandes que por vezes vale à pena pergunta se, na realidade, uma nova Constituição não foi promulgada (como é o caso da emenda $\mathrm{n}^{\circ}$ à Constituição brasileira de 1969). Existem outras maneiras de quantificar o tamanho de textos constitucionais que de fato mede o crescimento (ou redução) de Constituições, a 
MAC utilizada nesse trabalho é uma delas ${ }^{31}$. No caso brasileiro, a combinação entre heterogeneidade parlamentar e procedimento qualificado para alterar o texto constitucional não apenas não impediu que diversas emendas fossem aprovadas, mas de fato parece ter aumentado sensivelmente o tamanho delas.

Não é possível afirmar isso categoricamente, pois não tenho um contrafactual, mas os dados certamente permitem teorizar que as emendas que efetivamente são aprovadas dentro de regras mais rígidas e em contextos de preferências heterogêneas tendem a ser mais longas, contendo acordos de tipo logrolling, e garantias mútuas entre as distintas forças políticas representadas na maioria constitucional. Os trabalhos sobre o impacto de perfis de assembleias constituintes em textos constitucionais apontam nesse sentido ${ }^{32}$, inclusive no caso brasileiro ${ }^{33}$, a despeito do contexto de assembleia constituinte ser bem distinto daquele de emendamento ordinário ${ }^{34}$.

\subsection{Conclusões}

Realizei três críticas à suposição teórica de que maior rigidez constitucional produz menor emendamento de Constituições. A primeira é metodológica, direcionada à construção do índice de rigidez constitucional de Donald Lutz, que é amplamente utilizado para demonstrar essa relação. Demonstro que o índice criado por Lutz é baseado num raciocínio circular, e que é necessário criar medidas independentes de emendamento constitucional e rigidez constitucional, para verificar o impacto de uma coisa sobre a outra, coisa que Lutz não faz.

Na segunda crítica, recupero a teoria de atores com poderes de veto, que está por trás da suposição de que maior rigidez leva a menos emendamento constitucional, argumentando que os trabalhos comparativos que relacionam as duas coisas não fazem nenhuma avaliação sobre a constelação política na qual a regra está operando, algo necessário para a compreensão de uma Constituição como um veto gate.

Por fim, recupero as conclusões do primeiro capítulo para desafiar o próprio funcionamento do mecanismo de restrição ao emendamento constitucional promovido pela ideia de rigidez. No caso brasileiro, o endurecimento constitucional, aliado ao

\footnotetext{
${ }^{31}$ Para uma análise mais detalhada sobre as diferentes maneiras de medir Constituições e seu impacto sobre a análise, ver o apêndice metodológico.

${ }^{32}$ Ver, por exemplo, Elkins, Ginsburg e Melton (2009) e Jack Knight (2001).

${ }^{33}$ Praça e Noronha (2011, no prelo)

${ }^{34}$ Mas veja Ran Hirschl (2004) para uma visão que aproxima as duas coisas.
} 
detalhamento de uma Constituição e a um Executivo que, conquanto bastante poderoso, precisa pagar tributo a uma supermaioria parlamentar heterogênea, parece ter levado a mais e não a menos emendamento da Constituição. Contudo, os dados não são conclusivos.

Antevejo duas estratégias para melhor testar qual a relação entre heterogeneidade parlamentar, rigidez constitucional e emendamento de uma Constituição. A primeira, e mais ambiciosa, é comparativa. Seria necessário escolher outros países que também possuam Constituições detalhadas em contextos de governos de coalizão, e aplicar o mesmo tipo de coleta de dados feita aqui para o caso brasileiro. Índia e México são fortes candidatos, pois possuem Cartas razoavelmente detalhadas (ver Arantes e Couto 2010), e governos de coalizão, pelo menos no que diz respeito ao quórum constitucional. Além disso, ambos os países passaram por grandes flutuações na heterogeneidade de suas coalizões ao longo de suas já longas vidas constitucionais, sendo que o México saiu de um regime de partido único para outro no qual existe efetiva competição partidária. Essa variação na heterogeneidade das maiorias constitucionais permitiria testar a relação entre heterogeneidade e emendamento constitucional, contudo, seria necessário criar algum indicador de "heterogeneidade".

A segunda estratégia é menos ambiciosa, e seria limitada ao caso brasileiro. É possível aplicar a divisão de dispositivos da MAC a outros tipos de modalidade legislativa (leis ordinárias, leis complementares, medidas provisórias). Dessa maneira, não apenas é possível medir exatamente qual o impacto dos poderes constitucionais da Presidência da República na produção legislativa (iniciativa exclusiva, poder de veto parcial e medidas provisórias), mas também descobrir se, com o aumento da dificuldade de aprovação de algo do interesse do Executivo através da variação na modalidade legislativa, ocorre também maior crescimento das peças legislativas em questão. Os resultados para a relação entre heterogeneidade política e emendamento constitucional seriam menos significativos não apenas por restringirem-se à experiência de um único país (e uma única Constituição), mas também porque se estaria comparando emendas constitucionais com outros tipos de matérias legislativas. Mesmo assim, isso traria evidência indireta do funcionamento do mecanismo em questão. Criar e resolver esses, quebra-cabeças, contudo, fica para outro momento. 


\section{BIBLIOGRAFIA}

ABRUCIO, Fernando L. (1998). Os Barões da Federação. Os Governadores e a Redemocratização Brasileira. São Paulo. Departamento de Ciência Política da USP/Hucitec;

AMES, Barry (2003), Entraves da Democracia no Brasil. Rio de Janeiro. Fundação Getulio Vargas.

AMORIM NETO, Octavio, COX, Gary e MCCUBBINS, Mathew (2003). "Agenda Power in Brazil's Câmara dos Deputados (1989-98)". World Politics, vol. 55, nº 4. pp. $1-46$;

ARANTES, Rogério B. ; COUTO, Cláudio G. (2011) “Constitutionalizing Policy: The Brazilian Constitution of 1988 and its Impact on Governance" (no prelo). in Nolte, Detlef e Schilling-Vacaflor, Almut. New Constitutionalism in Latin America from a Comparative Perspective: A step towards good governance? (2010) “Construção Democrática e Modelos de Constituição”. Revista Dados. Rio de Janeiro. Impresso. v. 53. pp. 545-585. (2009), “Uma constituição incomum”. Carvalho, M. A. R.; Araújo, C; Simoes, J. A. (Org.). A constituição de 1988. Passado e Futuro. São Paulo. Aderaldo \& Rothschild: Anpocs. pp. 17-51. (2008). “A constituição sem fim”. Sérgio Praça; Simone Diniz. (Org.). Vinte anos de Constituição. São Paulo. Paulus. pp. 31-60.

ARRETCHE, Marta (2009). “Continuidades e descontinuidades da Federação Brasileira: de como 1988 facilitou 1995. Revista Dados. Rio de Janeiro, v. 52, n. 2. pp. $377-423$.

ARRETCHE, Marta; RODDEN, Jonathan (2004). "Política distributiva na Federação: estratégias eleitorais, barganhas legislativas e coalizões de governo". Revista Dados. Rio de Janeiro, v. 47, n. 3. pp. 549-576. 
Assembléia Nacional Constituinte. Comissão de Sistematização. Projeto de Constituição - Substitutivo do Relator. Brasília, Centro Gráfico do Senado Federal, agosto de 1987.

COUTO, Cláudio Gonçalves (2005). "Constituição, competição e políticas públicas". Revista Lua Nova, São Paulo, n. 65, p. 95-135.

COUTO, Cláudio Gonçalves e ARANTES, Rogério Bastos (2006). "Constituição, governo e democracia no Brasil”, Revista Brasileira de Ciências Sociais, v. 21, n. 61. pp. 41-62.

COUTO, Cláudio Gonçalves (1997). "A agenda constituinte e a difícil governabilidade". Lua Nova: revista de cultura e política, São Paulo, n. 39, p. 33-52. COX, Gary and MCCUBBINS, Matthew (1999). "The institutional determinants of Economic Policy Outcomes" in Haggard, Stephan and McCubbins, Matthew (eds.). Presidents, Parliaments, and Policy. Cambridge. Cambridge University Press.

ELKINS, Zachary and GINSBURG, Tom and MELTON, James (2009). The Endurance of National Constitutions. Cambridge University Press.

FIGUEIREDO, Argelina Cheibub; LIMONGI, Fernando (2002). "Incentivos Eleitorais, Partidos e Política Orçamentária". Revista Dados. Rio de Janeiro, v. 45, n. 2. pp. 303 344.

(1999). Executivo e Legislativo na Nova Ordem Constitucional. Rio de Janeiro, Fundação Getulio Vargas Editora.

(1998). Reforma da Previdência e Instituições Políticas. Revista Novos Estudos. CEBRAP, São Paulo, v. 51, p. 63-90.

(1995). "Mudança constitucional, desempenho do legislativo e consolidação institucional". Revista Brasileira de Ciências Sociais, 10, 29. pp. 175-200.

(1993) Democracia ou reformas? : alternativas democráticas à crise política, 1961-1964. Sao Paulo. Paz e Terra.

FREITAS, Rafael; MOURA, Samuel \& MEDEIROS, Danilo (2009). "Procurando o Centrão: direita e esquerda na Assembléia Nacional Constituinte, 1987-1988”. 
Carvalho, Maria A. R.; Araújo, Cícero \& Simões, Júlio Assis. (orgs.) A Constituição de 1988: passado e futuro. São Paulo, Ed. Hucitec. pp. 101-135.

GOMES, Sandra (2006). “O Impacto das Regras de Organização do Processo Legislativo no Comportamento dos Parlamentares: um Estudo de Caso da Assembléia Constituinte (1987-1988)". Revista Dados, v. 49. pp. 87-118.

HIRSCHL, Ran (2004). Towards Juristocracy: the origins and consequences of the new constitutionalism. Cambridge, Harvard University Press.

IMMERGUT, Ellen (1992). “A lógica da política de saúde na França, na Suiça e na Suécia”. Sven Steinmo, Kathleen Thelen \& F. Longstreth. Structuring Politics Historical Institutionalism in Comparative Analysis. Nova York, Cambridge University Press.

KNIGHT, Jack (2001). "Institutionalizing constitutional interpretation”, in Ferejohn, John; Rakove, Jack \& Riley, Jonathan. (eds.) Constitutional culture and democratic rule. New York, Cambridge University Press. pp. 361-391.

LIJPHART, Arend (2003). Modelos de Democracia. Desempenho e padrões de governo em 36 países. Rio de Janeiro: Civilização Brasileira.

LIMONGI, Fernando; FIGUEIREDO, Argelina, (2005). Processo orçamentário e comportamento Legislativo: emendas individuais, apoio ao Executivo e programas de governo. Revista Dados. Rio de Janeiro, v. 48, n. 4, Dec. pp. 737-776

LORENZ, Astrid (2005). "How to measure constitutional rigidity: four concepts and two alternatives". Journal of Theoretical Politics; 17; p. 339-361.

LUTZ, Donald S. (2006). Principles of Constitutional Design. Cambridge. Cambridge University Press.

MAINWARING, Scott P (2001). Sistemas partidarios em novas democracias: o caso do Brasil. Porto Alegre: Mercado Aberto. Rio de Janeiro. FGV.

MARTINEZ-LARA, Javier (1996). Building Democracy in Brazil. The Politics of Constitutional Change, 1985-95. New York, St. Martin's Press. 
MELO, Marcus (2007). "Hiperconstitucionalização e qualidade da democracia: mito e realidade" In Melo, Carlos Ranulfo \& S|ez, Manuel Alc|ntara (orgs.). A democracia brasileira: balanço e perspectivas para o século 21. Belo Horizonte. UFMG, Humanitas. pp. 237-265.

PEREIRA, Carlos; MUELLER, Bernardo (2002). “Comportamento Estratégico em Presidencialismode Coalizão: As Relações entre Executivo e Legislativo na Elaboração do Orçamento Brasileiro". Revista Dados. Rio de Janeiro, v. 45, n. 2. pp. 265-301. (2000). "Uma teoria da preponderância do Poder Executivo: o sistema de comissões no Legislativo brasileiro". Revista Brasileira de Ciências Sociais. São Paulo, v. 15, n. 43, June. pp. 45-67

PETERLEVITZ, T (2010). Boterismo constitucional en Colombia? Un análisis de la Constitución de 1991 y de sus reformas. In: II Congreso de Ciencia Política, Asociación Colombiana de Ciencia Política, Barranquilla, Colombia.

PIERSON, Paul. (2004), Politics in Time: History, Institutions and Social Analysis. Princeton, Princeton University Press.

PILATTI, Adriano. A Constituinte de 1987-1988: Progressistas, Conservadores, Ordem Econômica e Regras do Jogo. Rio de Janeiro, Ed. Lumen Júris, 2008.

PRAÇA, Sérgio e NORONHA, Lincoln (2011). "Políticas públicas e descentralização legislativa da assembléia constituinte brasileira, 1987-1988". Revista Brasileira de Ciências Sociais. No prelo.

SARTORI, Giovanni (2001). Ingeniería constitucional comparada. Una investigación de estructuras, incentivos y resultados, 2a. ed., México, Fondo de Cultura Económica.

SHUGART, Mathew e CAREY, John (1992). Presidents and Assemblies: Constitutional Design and Electoral Dynamics. New York, Cambridge University Press.

SOUZA, Celina (2008). "Regras e Contexto: As Reformas da Constituição de 1988". Revista Dados, vol. 51, nº 4, p. 791-823.

SOUZA, Celina (2003a). "Federalismo e conflitos distributivos: disputa dos estados por recursos orçamentários federais”. Revista Dados. Rio de Janeiro, v. 46, n. 2. pp. 345384. 
SOUZA, Celina (2001). "Federalismo e descentralização na Constituição de 1988:

processo decisório, conflitos e alianças". Revista Dados, v. 44, n. 3. pp. 513- 560.

SOUZA, Márcia Teixeira de (2003b). "O processo decisório na Constituição de 1988:

práticas institucionais", Lua Nova, v. 58. pp. 37-59. 